\title{
HAGUE INTERNATIONAL CHILD ABDUCTION CONVENTION: A PROGRESS REPORT
}

\author{
LINDA SILBERMAN*
}

\author{
SUMMARY
}

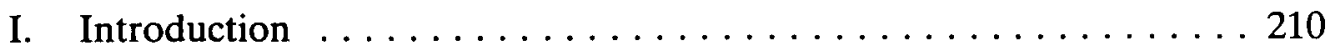

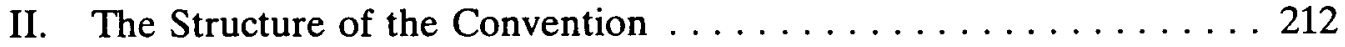

III. Implementation of the Convention $\ldots \ldots \ldots \ldots \ldots \ldots \ldots \ldots 215$

IV. The U.S. Experience with the Convention $\ldots \ldots \ldots \ldots \ldots \ldots \ldots 216$

V. Case Law Under the Convention $\ldots \ldots \ldots \ldots \ldots \ldots \ldots \ldots 217$

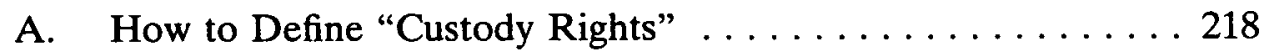

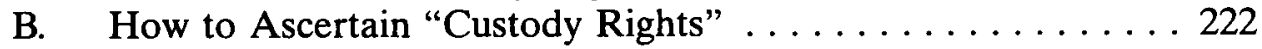

C. What Constitutes "Habitual Residence" ............. 225

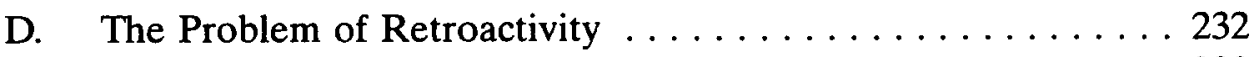

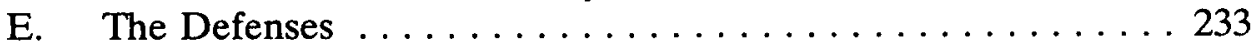

F. Special Problem of Access Rights . . . . . . . . . . . 247

VI. Relationship of the Convention to Other Custody Laws in the

United States . . . . . . . . . . . . . . . . . . . . . . 249

VII. Some Observations about the Convention

A. Reasons for the Convention's Success: Treaty Structure and Hague Conference Oversight . . . . . . . . . 257

B. Some Remaining Problems

1. Broader Adoption of the Treaty: Cultural Issues ...... 264

\section{Copyright $(01994$ by Law and Contemporary Problems}

* Professor of Law, New York University School of Law.

My deep appreciation to Adair Dyer, Esq., First Secretary, Hague Conference on Private International Law, for making research materials at the Hague available to me and for giving so generously of his time and energy in meeting with me and commenting on an earlier draft. In addition, through Mr. Dyer's good offices, I was privileged to attend the Second Special Commission Meeting on the operation of the Hague Convention on the Civil Aspects of International Child Abduction as an expert consultant on January 18-21, 1993, giving me direct access to important information about the operation of the Convention. I am also indebted to Peter H. Pfund, Esq., Assistant Legal Adviser for Private International Law, U.S. Department of State, for keeping me abreast of ongoing developments and providing the cooperation of his office. Thanks also to William Hilton, Esq., who made available his computerized bulletin board of Hague materials, including many of the cases discussed herein, to Ms. Linda Donahue, Mr. Jack Markey, and Mr. James Schuler in the Consular Office of the Department of State for providing statistical and other information, and to Robert Arenstein, Esq., who offered the benefit of his wisdom and expertise in the actual handling of Convention matters. My research assistants, Glenn Greenwald and Chuck Davidson of New York University School of Law, were of great help, and the Filomen D'Agostino and Max E. Greenberg Research Fund at the New York University School of Law provided financial support. 
2. Beware the Child Savers ... . . . . . . . . . . . 267

3. Unanswered Questions . . . . . . . . . . . . . . . . . . 269

\section{INTRODUCTION}

The Hague Convention on the Civil Aspects of International Child Abduction $^{1}$ was adopted on October 25, 1980, at the Fourteenth Session of the Hague Conference on Private International Law in Plenary Session by unanimous vote of the twenty-three member states. ${ }^{2}$ When opened for signature on October 25 , 1980, the Convention was signed by Canada, France, Greece, and Switzerland. ${ }^{3}$ It was signed on behalf of the United States on December $23,1981{ }^{4}$ With the enactment of implementing legislation on April 29, 1988, ${ }^{5}$ the treaty entered into force for the United States on July 1, 1988. Its objective is to protect children from wrongful international removals or retentions from their lawful custodians. ${ }^{6}$ Notwithstanding the reference to "abduction" in its title, the Convention remedies violations of child custody and visitation rights more generally and provides a set of rules for obtaining the return of a child who has been taken to another country in violation of these rights. ${ }^{7}$ The Convention procedures do not

1. S. Treaty Doc. No. 11, 99th Cong., 1st Sess., 19 I.L.M. 1501 (1980) [hereinafter Hague Convention]. For a discussion of the impetus for an international convention on custody, see Brigitte M. Bodenheimer, The Hague Draft Convention on International Child Abduction, 14 FAM. L.Q. 99 (198081) (The late Professor Bodenheimer was a member of the U.S. delegation that participated in the drafting of the Convention.).

2. Letter of Submittal from George P. Shultz, Secretary of State, to President Ronald Reagan (Mar. 26, 1986), reprinted in 51 Fed. Reg. 10,496 (1986); see also Elisa Pérez-Vera, Explanatory Report [hereinafter Perez-Vera Report], in 3 Hague Conference on Private InTERnational Law, ACTS AND DOCUMENTS OF THE FOURTEENTH SESSION, CHILD ABDuCTION 426 (1982) [hereinafter ACTS AND DOCUMENTS, CHILd ABDUCTION].

3. Letter of Submittal, supra note 2.

4. Id. The Senate gave its advise and consent on October 9, 1986.

5. See International Child Abduction Remedies Act, Pub. L. No. 100-300, 102 Stat. 437 (1988) (codified as amended at 42 U.S.C. $\$ \S 11601-11610$ (1989)). Congressional hearings on international abduction were held in connection with the legislation. See International Child Abduction Act: Hearings on H.R. 2673 and H.R. 3971 Before the Subcomm. on Administrative Law and Governmental Relations of the House Comm. on the Judiciary, 100th Cong., 2d. Sess. (1988).

6. See Hague Convention, supra note 1, art. 1, S. TREATY DoC. No. 11 at 7, 19 I.L.M. at 1501. For a general discussion on the need for such a Convention and its objectives, see Robin Jo Frank, Note, American and International Responses to International Child Abductions, 16 N.Y.U. J. INT'L L. \& POL. 415 (1984); Dana R. Rivers, Comment, The Hague International Child Abduction Convention and The International Child Abduction Remedies Act: Closing Doors to the Parent Abductor, 2 TRANSNAT'L LAW. 589 (1989); Barbara Ullman Schwerin, Note, The Hague Convention on International Child Abduction: A Practical Application, 10 LOY. L.A. INT'L \& COMP. L.J. 163 (1988); Comment, The Hague Convention on the Civil Aspects of International Child Abduction, 9 N.C. J. INT'L L. \& COM. REG. 463 (1985).

7. The Convention and the U.S. implementing legislation provide for a civil remedy only. In December 1993, the President signed into law the International Parental Kidnapping Crime Act of 1993, Pub. L. 103-173, codified as 18 U.S.C. $\$ 1204$, which makes removal of a child from the United States or retention of a child outside of the United States with intent to obstruct a parent's right to custody the basis of a federal crime. The House Report stated that the Hague Abduction Convention had facilitated the return of abducted children in countries that were signatories to the Convention, but observed that many countries were not parties to the Convention; the Report noted that creation of a federal felony offense allowed the United States to request extradition from countries with which it has extradition 
purport to provide custody or visitation standards or to investigate the merits of custody disputes, but only to assure the return of children to their habitual residences.

This article, written in connection with the Hague Conference's ${ }^{8}$ centennial year, offers a brief overview of this Convention-one that I believe has been a great success. ${ }^{9}$ In reviewing both the structure of the Convention and its implementation in various countries, the article highlights those aspects of the Convention that have been the most troublesome both within the United States and elsewhere and makes useful suggestions for improving its effectiveness. Hopefully, observations about this Convention will prove useful in assessing the role of the Hague Conference in the convention process more generally and in identifying the ways in which its cooperative processes and superintendence can be most effectively utilized.

treaties and provided a basis for a federal warrant, thereby enhancing diplomatic efforts in seeking the assistance of foreign governments to return abducted children. H.R. Rep. No. 103-390, 103d Cong., 1st Sess. 1, 3 (1993), reprinted in 1993 U.S.C.C.A.N. 2419-2421. The President's signing statement expressly referred to the Hague Abduction Convention, noting that it was "the sense of the Congress that proceedings under the Hague Convention, where available, should be the 'option of first choice' for the left-behind parent" and that the criminal statute "should be read and used in a manner consistent with the Congress' strong expressed preference for resolving these difficult cases, if at all possible, through civil remedies." 1993 U.S.C.C.A.N. 2424-1. For a more general discussion of how criminal proceedings and extradition intersect with the Convention, see PERMANENT BUREAU OF THE HaGUe CONFERENCE REPORT OF THE SECOND SPECIAL COMMISSION MEETING TO REVIEW THE OPERATION OF THE HAGUE CONVENTION ON THE CIVIL ASPECTS OF INTERNATIONAL CHILD ABDUCTION, reprinted in 33 I.L.M 225, 249-50 (1994) [hereinafter SECOND SPECIAL COMMISSION REPORT].

8. For a discussion of the role of the Hague Conference, see Georges A. L. Droz \& Adair Dyer, The Hague Conference and the Main Issues of Private International Law for the Eighties, 3 Nw. J. INT'L. L. \& BUS. 155 (1981).

9. For an excellent overview of the Convention, highlighting its successes and failures, see Adair Dyer, The Hague Convention on the Civil Aspects of International Child Abduction-Towards Global Cooperation, 1 INT'L J. CHILDREN's RIGHTS 273-92 (1993). Domestic and foreign case law interpreting key provisions under the Convention is analyzed in Linda Silberman, Hague Convention on International Child Abduction: A Brief Overview and Case Law Analysis, 28 FAM. L. Q. 9 (Spring 1994), and the vital role of the Central Authorities is discussed in Carol S. Bruch, The Central Authority's Role Under the Hague Child Abduction Convention: A Friend in Deed, 28 FAM. L. Q. 35 (Spring 1994) [hereinafter Bruch, Central Authority's Role]. See also ABA CENTER ON CHILDREN AND THE LAw, NorTH AMERICAN SYMPOSIUM ON INTERNATIONAL CHILD ABDUCTION: HOW TO HANDLE INTERNATIONAL CHILD ABDUCTION CASES (1993) [hereinafter ABA SYMPOSIUM]. The proceedings of that symposium are summarized in Patricia M. Hoff, An Overview of the North American Symposium on International Child Abduction, 28 FAM. L. Q. 1 (Spring 1994). 


\section{THE Structure OF THE CONVENTION}

For a variety of reasons, rehearsed elsewhere in the literature,$^{10}$ the Hague Conference proceeded with a Convention that is "procedural" and "jurisdictional" in nature. Thus, the Convention does not offer uniform international standards for determining custody rights nor does it provide for enforcement of custody decrees rendered by another foreign state. ${ }^{11}$ Rather, the approach of the Convention is to deter both wrongful "removals" of a child from one country to another and wrongful "retentions" by providing for procedures to assure that all issues of custody be litigated in the jurisdiction where a child was "habitually resident." 12 Countries adhering to the treaty ${ }^{13}$ agree to return all wrongfully removed or retained children to the state of the child's habitual residence so that authorities in that state may exercise the power to determine the long-term custody between the disputing parties.

The heart of the Convention is set forth in Articles 3 and 12. Article 3 defines a wrongful removal or retention as when there is a "breach of rights of custody ... under the law of the State in which the child was habitually resident immediately before the removal or retention; and ... those rights were actually

10. See A.E. Anton, The Hague Convention on International Child Abduction, 30 INT'L \& COMP. L.Q. 537, 540-43 (1981) (explaining choice of approach); Brigitte M. Bodenheimer, The Hague Draft Convention on International Child Abduction, 14 FAM. L.Q. 99, 102-03 (1980) (discussing procedural nature of the Convention); see also Adair Dyer, Report on International Child Abduction by One Parent (Prelim. Doc. No. 1 of Aug. 1978), in ACTS AND DoCumENTs, CHILD ABduCTION, supra note 2, at 12-31 (discussing expedited return of child as better than enforcement of custody orders as remedy for international child abduction).

11. The other important treaty on international child custody is the European Convention on Recognition and Enforcement of Decisions Concerning Custody of Children and on Restoration of Custody of Children, May 20, 1980, 19 I.L.M. 273 (1980) [hereinafter Strasbourg Convention]. See generally R. L. Jones, Council of Europe Convention on Recognition and Enforcement of Decisions Relating to the Custody of Children, 30 INT'L \& COMP. L.Q. 467 (1981). As its title indicates, the thrust of the Strasbourg Convention is the enforcement of decrees, and it applies only when there is an existing custody decree. Under the Strasbourg Convention, an expeditious enforcement procedure is provided when there is common nationality; but in other cases, a more complicated inquiry into the original custody court's jurisdiction is necessary, and numerous "best interest" exceptions can be invoked. For a more detailed comparison of the two conventions, see John M. Eekelaar, International Child Abduction by Parents, 32 U. TORONTO L.J. 281, 321-25 (1982). See also Frank, supra note 6, at 436-49. For other examples of the treatment of children in private international law, see Adair Dyer, Childhood's Rights In Private International Law, 2 AustRalian J. FAM. L. 103 (1991).

12. Hague Convention, supra note 1, art. 12, S. TREATY DOC. No. 11 at 9, 19 I.L.M. at 1502.

13. Members of the Hague Conference at the time of the adoption of the Convention can become signatories to the Convention. Hague Convention, supra note 1, art. 37, S. TREATY DoC. No. 11 at 13 , 19 I.L.M. at 1504. Other countries may accede to the Convention, but the accession has effect only as to those countries that declare their acceptance. Id. arts. 37 and 38, S. TREATY DoC. No. 11 at 14,19 I.L.M. at 1503. As of July 19, 1994, 23 States had ratified the Convention: Argentina, Australia, Austria, Bosnia-Herzegovina, Canada, Croatia, Denmark, Finland, France, Germany, Greece, Ireland, Israel, Luxembourg, Macedonia, Netherlands, Norway, Portugal, Spain, Sweden, Switzerland, United Kingdom, and the United States. Fifteen other States have acceded to the Convention: Bahamas, Belize, Burkina Chile, Ecuador, Faso, Honduras, Hungary, Mauritius, Mexico, Monaco, New Zealand, Panama, Poland, Romania, and Slovenia. In addition, Saint Kitts and Nevis deposited its instrument of accession, and the Convention will enter into force on August 1, 1994. Hague Conference on Private International Law, Circular No.1 (94), July 19, 1994. 
exercised, whether jointly or alone, or would have been so exercised but for the removal or retention."14 Article 12 provides the remedy for such a wrongful removal or retention. When proceedings are brought within one year of the child's wrongful removal or retention in the contracting state where the child is now physically present, judicial or administrative authorities within that state "shall order the return of the child forthwith." 15 When proceedings are brought after the expiration of the one-year period, the authorities in the contracting state "shall also order the return of the child, unless it is demonstrated that the child is settled in its new environment."16 When such a showing is made, the court has discretion about whether or not to order return.

Those opposing return of a child have a limited number of defenses. Article 13a states that authorities are not bound to order return of the child if "the person, institution or other body having the care of the person of the child was not actually exercising the custody rights at the time of removal or retention or had consented to or subsequently acquiesced in the removal or retention." 17 Another line of defense is provided in Article 13b, which permits a refusal to return if "there is a grave risk that his or her return would expose the child to physical or psychological harm or otherwise place the child in an intolerable situation." 18 Article 13 goes on to permit a child of suitable age and maturity to object to being returned. ${ }^{19}$ A last exception that justifies refusal to return a child is found in Article 20, which applies if "fundamental principles of the requested state relating to the protection of human rights and fundamental freedoms" would not permit the return. ${ }^{20}$

As we shall see, several of the concepts enumerated above are unique to this Convention and have spawned judicial interpretations regarding their meaning. Failure to acquire a consistent interpretation of the treaty will undermine its value as a vehicle for ensuring the return of children wrongfully removed or retained in the international setting. It is in this sense that the Hague Conference, through its coordination with the various contracting states and the institution of a Central Authority in each contracting state, has been pivotal in enhancing the effectiveness of the treaty.

Article 6 of the Convention requires each contracting state to designate a Central Authority to coordinate various tasks in effectuating the return of a child. ${ }^{21}$ Article 7 spells out various aspects of the cooperation between Central

14. Hague Convention, supra note 1, art. 3, S. TREATY DOC. No. 11 at 7, 19 I.L.M. at 1501 ,

15. Id. art. 12, S. TREATY DOC. No. 11 at 9, 19 I.L.M. at 1502.

16. Id.

17. Id. art. 13a, S. TREATY Doc. No. 11 at 10, 19 I.L.M. at 1502.

18. Id. art. 13b, S. TREATY DOC. No. 11 at 10, 19 I.L.M. at 1502 . See generally James T. Matthews, Recent Developments, United States Implementation of the Hague Convention on the Civil Aspects of International Child Abduction, 24 STAN. J. INT'L L. 289, 298-300 (1987).

19. Hague Convention, supra note 1 , art. 13, S. TREATY DoC. No. 11 at 10, 19 I.L.M. at 1502.

20. Id. art. 20, S. TREATY Doc. No. 11 at 11,19 I.L.M. at 1503. Note that even when defenses have been established, the court has discretion whether or not to order return.

21. In the United States, there is a single Central Authority-the Office of Citizens Consular Services in the Bureau of Consular Affairs of the Department of State (now called Office of Children's 
Authorities and other authorities envisioned by the Convention. Specifically, it directs Central Authorities to take measures to discover the whereabouts of a child, to secure provisional measures to prevent further harm to the child, to secure the voluntary return of the child, to exchange information about the child and about the relevant laws, to initiate or facilitate initiation of proceedings and access to legal counsel where appropriate, to provide administrative arrangements to secure return of the child, and to provide a flow of information about the progress of proceedings and application of the Convention. ${ }^{22}$ The Central Authority of a state to which a child is taken responds to "incoming requests" for return by helping to locate a child, by trying to secure the voluntary return of the child, and by providing information about how to proceed to applicants and to the Central Authority in the state from where the child was taken, as well as facilitating access to legal assistance and advice. In some countries, the Central Authority itself initiates proceedings to secure the return of the child. ${ }^{23}$ The Central Authority in the state from which the child has been removed responds to "outgoing requests" by helping an applicant prepare and process a case, providing information about the options in the foreign state, and contacting the relevant Central Authority in the state to which the child has been taken.

Article 8 provides that a person claiming rights under the Convention may apply either to the Central Authority of the child's habitual residence or to the Central Authority of any other contracting state for assistance in securing the return. ${ }^{24}$ Article 9 directs a Central Authority receiving an application to transmit the application to the Central Authority of that contracting state where the child is believed to be. Use of the Central Authority is optional, and a party

Issues). See 53 Fed. Reg. 30,637 (1988); 22 C.F.R. \& 94.2 (1993). For a discussion of the operation of the U.S. Central Authority, see Peter Pfund, The Hague Convention on International Child Abduction, the International Child Abduction Remedies Act, and the Need for Availability of Counsel for All Petitioners, 24 FAM. L.Q. 35, 45-51 (1990). In Canada, there is a federal Central Authority in Ottawa, and in addition, each province and territory has appointed its own Central Authority in the offices of its Attorney General or Department of Justice. On the Canadian model, see Vaughan Black, Provincial Legislation-The Hague Convention, in CHILD CUSTODY LAW AND PRACTICE 3-9 (J. McLeod ed., 1992). In Australia, the Central Authority is within the federal Attorney-General's Department in Canberra, Australian Capital Territory. Officials there delegate the matter to child welfare departments of the relevant state or territory. See Mr. Justice Peter Nygh, The Hague Convention at Work in Australia, 15 FAM. ADVOCATE, Spring 1993, at 24. For a comprehensive report on the operations of the Central Authorities, see Bruch, Central Authority's Role, supra note 9.

22. Hague Convention, supra note 1, art. 7, S. TREATY DoC. No. 11 at 8, 19 I.L.M. at 1502.

23. For example, in Spain, the staff at the Central Authority in Madrid attempts to represent petitioners throughout the country. In France, cases are referred from the Central Authority in the federal Ministry of Justice to local prosecutors. In other countries, proceedings are brought by private counsel, but the Central Authority may play a role in trying to find appropriate counsel. See generally Bruch, Central Authority's Role, supra note 9; Carol S. Bruch, International Child Abduction Cases: Experience Under the 1980 Hague Convention, in PARENTHOOD IN MODERN SOCIETY: LEGAL AND SOCIAL IsSUES FOR THE TWENTY-FIRST CENTURY 361-63 (J. Eekelaar \& P. Sarcevic eds., 1993) [hereinafter Bruch, International Child Abduction Cases]. In the United States, which has made reservations under Articles 26 and 42, and is therefore not responsible for costs or attorneys' fees resulting from legal proceedings, the U.S. Central Authority has made a continuing effort to identify and enlist the assistance of the private bar on behalf of applicants.

24. Hague Convention, supra note 1, art. 8, S. TREATY DOC. NO. 11 at 8, 19 I.L.M. at 1502. 
may bypass the Central Authority in both the requested and requesting states and bring its own action for return of the child. ${ }^{25}$ In most cases, however, it appears that the Central Authorities have played an important role in processing applications, contacting judicial and administrative authorities, disseminating information, and expediting the process. ${ }^{26}$

The Convention also places obligations on the judicial or administrative authorities of contracting states responsible for effecting rights under the Convention. Article 11 instructs that they "act expeditiously in proceedings for the return of children." If no decision has been reached within six weeks from the commencement of proceedings, there is a "right to request a statement of the reasons for the delay."27

Visitation, or "rights of access," are dealt with separately from "custody rights." A separate section, Article 21, provides that a party may apply to the Central Authority to secure "the effective exercise of rights of access" and that the Central Authority may initiate or assist in the institution of proceedings to secure such rights. However, a breach of bare access rights does not trigger a remedy of return of the child.

Article 26 addresses the issue of costs and expenses arising from proceedings under the treaty. Unless a reservation is made, an applicant is not required to pay for the costs and expenses of the proceedings, including those arising from the participation of legal counsel. ${ }^{28}$ In effect, the state itself is required to bear the cost of proceedings and to provide legal counsel. A state may, however, except itself from assuming costs arising from the participation of legal counsel or from court proceedings when such costs are not covered by its general system of legal aid. ${ }^{29}$ The United States has made such an Article 42 reservation. ${ }^{30}$

\section{III}

\section{IMPLEMENTATION OF THE CONVENTION}

Most countries have passed specific legislation to implement the Convention. $^{31}$ In 1988, the United States Congress enacted the International Child

25. Article 29 of the Convention expressly states that a person or institution who claims that there has been a breach of rights under the Convention is not precluded from applying directly to the authorities of a contracting state, whether or not under the provisions of the Convention. Hague Convention, supra note 1, S. TREATY DOC. No. 11 at 12, 19 I.L.M. at 1504 . Such an application can be made even if a Central Authority rejects an application. See SECOND SPECIAL COMMISSION REPORT, supra note 7 , at 56 .

26. Just how the U.S. Central Authority can help is spelled out in Philip Schwartz, Getting a Child Back, 15 FAM. AdvoCATE, Spring 1993, at 42.

27. Hague Convention, supra note 1, art. 11, S. TREATY DoC. No. 11 at 9, 19 I.L.M. at 1502.

28. Id. art. 26, S. TREATY DOC. No. 11 at 12, 19 I.L.M. at 1503.

29. Id. 57.

30. For discussion of the difficulty engendered by the reservation, see text accompanying notes 255 -

31. In England, treaties are not self-executing; thus, implementing legislation was required to effectuate the treaty. In the United States, the Convention was self-executing, but implementing legislation was nonetheless thought to be desirable. See Frank, supra note 6, at 465-68. In Canada, implementing legislation was enacted in each province. 
Abduction Remedies Act ("ICARA") to implement the treaty within the United States. ${ }^{32}$ The statute authorizes parties seeking to enforce rights under the Convention to file a petition in a court of appropriate jurisdiction in the place where the child is located. ${ }^{33}$ Both the state and federal courts are given jurisdiction to hear such petitions. ${ }^{34}$ Under the statute, the President is directed to designate a federal agency to serve as the Central Authority, ${ }^{35}$ and by Executive Order No. 12648, signed on August 11, 1988, the President designated the Department of State as the Central Authority.

Various procedural details for asserting a claim under the treaty, including issues of notice and burdens of proof, are addressed by the federal legislation. The elements for establishing a claim under the treaty and raising a defense follow traditional patterns, except that the Article 13b and Article 20 defenses-if the return would subject the child to a grave risk of harm, or create an intolerable situation, or is inconsistent with fundamental principles of human rights-must be proved by clear and convincing evidence. ${ }^{36}$ Provisional remedies authorized by state or federal law may be used in connection with an action under the Convention. ${ }^{37}$ ICARA also addresses the question of costs and fees, prohibiting the government from imposing any fee for administrative processing of applications under the Convention but stating that court costs in connection with proceedings and attorneys' fees, as well as travel costs in connection with return, will be borne by the applicant, unless covered by payments from legal assistance programs. ${ }^{38}$ The legislation also requires a court ordering return of the child to order the respondent to pay such fees, unless "clearly inappropriate." 39

\section{THE U.S. EXPERIENCE WITH THE CONVENTION}

Although the Convention has been in force in the United States only since 1988 , assessments of its value have been quite positive. The early optimism is consistent with Convention experience in other countries. Statistics compiled by the State Department as of January $1993^{40}$ analyzed both incoming and

32. International Child Abduction Remedies Act, 42 U.S.C. $\$ \S 11601-11610$ (1989). For background on this legislation, see Rivers, supra note 6, at 630-34.

33. 42 U.S.C. $\S 11603(b)$.

34. Id. § 11603(a).

35. Id. $\S 11606$.

36. Id. \& $11603(\mathrm{e})$.

37. Id. $\$ 11604$. The use of habeas corpus to locate the child or to secure return and prevent further flight is discussed in Lon Vinion, When Custody Conflicts Cross the Border, 15 FAM. ADVOCATE, Spring 1993 , at 30,34 .

38. 42 U.S.C. $\$ 11607(b)(2)$.

39. Id. § $11607(\mathrm{~b})(3)$.

40. These are the latest available statistics tracking dispositions in incoming and outgoing Hague cases via the U.S. Central Authority. More recent information with respect to the volume of Hague cases handled by the Central Authority through February 1994 is included in subsequent footnotes. The statistics are courtesy of Mr. Jack Markey and Mr. James Schuler, U.S. Department of State. 
outgoing Hague cases. Of the total 564 incoming cases, ${ }^{41} 43 \%$ (242 cases) resulted in a favorable disposition, meaning voluntary return or access, or courtordered return or access. ${ }^{42}$ Of the 162 cases that were processed through the courts, $91 \%$ resulted in return or access. ${ }^{43}$ A large number of the favorable dispositions were voluntary returns (39\%), suggesting that the Convention may be having an important enforcement role without the need for a formal court order. It is also likely that the pervasive role of the Central Authority in disseminating information to potentially breaching parties is having a significant impact in effectuating the return of children.

Of the total 664 outgoing cases, ${ }^{44} 40 \%$ (265 cases) resulted in a favorable disposition. $^{45}$ Of those 265 favorable dispositions, roughly $26 \%$ resulted in either voluntary return or access, and $74 \%$ resulted in court-ordered return or access. Of the total 227 cases that were processed in foreign courts, $85.9 \%$ resulted in return or access. These figures are quite impressive when compared to results of abductions in non-Hague cases, in which the Consular Office of the State Department is also involved. Central Authority statistics indicate that the favorable resolution rate for non-Hague cases has been only in the $20-25 \%$ range.

In comparing the operation of the Convention in the United States with that of our treaty partners, the incoming caseload in the United States has significantly more cases resolved voluntarily in both percentages and real numbers. In other member states, three of four decisions are court-ordered.

\section{V}

\section{CASE LAW UNDER THE CONVENTION}

Although reported cases in the United States are few, they, together with reported cases in other countries, highlight the more troublesome issues that arise under the Convention.

41. There has been an increasing awareness of the Convention. The incoming Hague caseload grew by $46 \%$ in 1992 . Id. The same trend continued in 1993, with 357 new incoming cases. Id.

42. Another $2 \%$ of the incoming cases (14 cases) resulted in a court-ordered denial of return or access, and $2 \%$ (11 cases) were disposed of by the child's reabduction. Id. In $18 \%$ of the incoming cases (101 cases), no action was taken because the Convention was not applicable, the application was withdrawn, or the child could not be located. Id. The remaining $35 \%$ of the 564 incoming cases (196 cases) were cases in progress. Id.

43. Of the voluntary dispositions, $34.3 \%$ ( 83 cases) resulted in return, and $4.54 \%$ (11 cases) resulted in access. Id. Of the court-ordered dispositions, $56.2 \%$ (136 cases) resulted in return and $4.96 \%(12$ cases) resulted in access. Id.

44. The number of outgoing Hague cases grew by $67 \%$ in 1992 . Id. The same trend continued in 1993, with 441 new outgoing cases. Id.

45. Another $5 \%$ of the total outgoing cases ( 32 cases) resulted in a court-ordered denial of return of access, and $1 \%$ ( 5 cases) were disposed of by the child's reabduction. Id. In $20 \%$ of the outgoing cases (101 cases), no action was taken. The remaining $34 \%$ of the 664 outgoing cases (196 cases) were cases in progress. Id. 


\section{A. How to Define "Custody Rights"}

The Hague Convention remedy of return of a child is provided when there has been a wrongful removal or retention of a child. Thus, a central issue in many Hague cases will be whether or not there has been such a wrongful removal or retention. Article 3 of the Convention states that the removal or retention of a child is wrongful where "it is in breach of rights of custody attributed to a person, an institution, or any other body, either jointly or alone under the laws of the State in which the child was a habitual resident immediately before the removal or retention" and "those rights were actually exercised . .. or would have been so exercised but for the removal or retention." 46 Thus, the question of when a party's "custody rights" have been breached becomes a critical inquiry.

Article 5 of the Treaty defines "rights of custody" as "rights relating to the care of the person of the child and, in particular, the right to determine the child's place of residence." 47 The relevant "rights of custody" are those of the state of habitual residence, a term not defined in the treaty. Rights of visitation, or "rights of access" as they are denominated in the Convention, involve the "right to take a child for a limited period of time to a place other than the child's habitual residence." 48 Article 21 authorizes the Central Authorities to facilitate and secure such rights of access, but interference with access rights does not trigger return of the child. ${ }^{49}$ Article 15 authorizes the judicial or administrative authorities of the requested state to request that an applicant obtain a decision or other determination from the state of the child's habitual residence that the removal or retention was wrongful within the meaning of Article $3 .{ }^{50}$

If there is a decree granting custody rights to one party, a removal of a child in violation of the decree will, of course, amount to a wrongful removal. Several Convention cases have raised questions, however, as to just when various types of parenting arrangements and custodial orders create custody rights. Generally speaking, if one parent has been granted custody via court order and the other parent has only visitation or access rights, the custodial parent is permitted to take the child to another country in violation of the visitation rights without risking a return order under the Convention. ${ }^{51}$ However, several courts have held that when a custodial agreement or decree prevents a parent from leaving the country with the child, such a restriction gives "custody rights" to the resident parent sufficient to invoke the Convention. In David S. v. Zamira S. ${ }^{52}$ for example, a Canadian mother brought her children to New York in violation

46. Hague Convention, supra note 1, art. 3, S. TREATY Doc. No. 11 at 7, 19 I.L.M. at 1501.

47. Id. art. 5a, S. TREATY Doc. No. 11 at 7, 19 I.L.M. at 1501.

48. Id. art $5 \mathrm{~b}$.

49. Id. art. 21, S. TREATY DOC. No. 11 at 11, 19 I.L.M. at 1503 .

50. Id. art. 15, S. TREATY Doc. No. 11 at 10,19 I.L.M. at 1503.

51. The Convention is quite clear that only "custody" rights and not "access" rights trigger an order of return.

52. 574 N.Y.S.2d 429 (Fam. Ct.), aff'd sub nom. In re Schnier, 17 Fam. L. Rep. (BNA) 1237 (N.Y. App. Div. Feb. 27, 1991). 
of a separation agreement with her husband that prevented her from relocating outside the Metropolitan Toronto area. Just as the mother was about to leave Canada, the husband obtained a court order to prevent her from leaving. On the husband's petition for return, the mother argued that only visitation rights were involved. The court rejected the contention, pointing to the mother's contumacious conduct in leaving Canada and to subsequent orders of the Ontario courts granting temporary custody to the father. These particular factors are dubious support for the creation of "custody rights" in this case. It is not clear that the restraint orders were issued prior to the mother's departure, and a custody order issued by a court after the removal of a child should be relevant only to the extent it evidences what the existing rights were at the time of removal. Nonetheless, the outcome comports with the spirit of the Convention, which is designed to preserve the parenting arrangements in place prior to the disruption and to have any modifications made in the state of habitual residence. In this respect, the father's situation in Zamira $S$. is correctly characterized as meeting the Article 5 definition of "custody rights" because he had a right to determine the child's place of residence, giving him more than mere visitation.

A similar situation existed in Navarro v. Bullock, ${ }^{53}$ where a separation agreement between the Spanish parents delineated "joint legal custody," with the mother having the children during the school year and the father during the summer, holidays, and alternate weekends. The mother was also permitted to take the children to California for one month during the summer in alternate years. After taking the children to California in 1988, the mother refused to return and indeed would not reveal the whereabouts of the children. Eventually, the father, with the help of the U.S. Central Authority, located the children and brought a petition under the Hague Convention; the children were ordered returned.

Decisions of most foreign courts on this issue are consistent with this position. The Court of Appeal in England rendered a similar decision in $C v$. $C{ }^{54}$ where an Australian decree giving "joint guardianship" to both parents was construed as establishing "custody rights" and prevented the mother from moving the child from Australia without the father's approval. And a decision

53. 15 Fam. L. Rep. (BNA) 1576 (Cal. Super. Ct. Sept. 1, 1989).

54. [1989] 2 All E.R. 465 (Eng. C.A. Dec. 14, 1988) (Australian decree in question granted "custody" to the mother and "joint guardianship" to both parents, and the English Court of Appeal held that the father had "custody rights" within the meaning of the Convention since the Australian guardianship order gave him the right to prevent the child's removal from Australia without his approval); Wolfe v. Wolfe, No. FP 743/92 (N.Z. D.C. Feb. 16, 1993) (available on Hilton BBS) (holding that an order enjoining both parents from removing the child from the jurisdiction gave the non-removing parent a right of custody within the meaning of Article 5). This case and others, as indicated, are available on Hilton House BBS, which is an electronic bulletin board system that provides information on the Convention and related legislation. Hilton BBS may be accessed through a computer modem at 408/2460387. The system requires a setting of $8-1-\mathrm{N}$. Hilton BBS will prompt the first-time caller for their first and last name and a password. For further information, consult ABA, INTERNATIONAL CHILD Abduction: A Guide to Applying the Hague Convention 96-97 (2d ed. 1993). The Hilton BBS operator may be contacted by voice mail at 408/246-8511. Messages will be returned by collect call. 
of the Israeli Supreme Court, Tournia v. Mechoulam ${ }^{55}$ ordered return of a child to France where the French divorce decree provided for joint custody and the mother had attempted to move to Israel without her husband's permission. In another case, a French appeals court also found that a restriction on movement was sufficient to establish "custody rights," decision $^{57}$ reached an opposite conclusion, holding that a mother who had been granted custody rights with a condition that she remain in England or Wales had not wrongfully removed her son when she moved with him to France, because only access rights were interfered with.

A careful analysis of the relevant law may be required in determining whether a party has "custody rights." As the first state Supreme Court to consider a Convention case, the Massachusetts Supreme Court in Viragh v. Foldes $^{58}$ refused to order return of a child to Hungary in a situation where the wife was granted custody and the husband was granted visitation. The court, interpreting Hungarian law, found that the Hungarian Guardianship Authority must consent before a child is permanently removed from Hungary. The court concluded that under these circumstances the Authority might have brought an action for return, but that the non-custodial father did not have the right to determine the place of residence and therefore did not have custody rights ${ }^{59}$ within the meaning of the Convention. ${ }^{60}$ This issue of third-party custody rights has arisen in other cases. The British Columbia Court of Appeal reversed a trial judge's order to return an Aleut Indian baby born out of wedlock in California and surrendered for adoption to prospective parents in British Columbia. ${ }^{61}$ The trial court had found that the Indian tribe had custody rights in the placement and adoption process under the Indian Child Welfare Act and ordered the child returned to California; however, the Court of Appeal ruled that since both parents had agreed that the child be given over for adoption, the tribe had no custody rights within the meaning of the Convention. Another recent court ruling in New Jersey found that German foster parents, who had de facto daily

55. Judgment of April 15, 1992 (Tournia v. Mechoulam), No. 1648/92, Isr. Sup. Ct. (available on Hilton BBS).

56. Judgment of Mar. 23, 1989 (Ministère Public v. M. B), Cour d'Appel d'Aix-en-Provence (Fr.) (on file with author).

57. Judgment of Mar. 17, 1992 (Ministère Public v. Mme Y), Trib. gr. inst. de Périgueux, D.S. Jur., June 18, 1992 (Fr.).

58. 612 N.E.2d 241 (Mass. 1993).

59. Compare the approach of one English court, which indicated that the breach of a territorial restriction by the custodial parent is itself a violation of "custody rights" and that a party can breach his or her own rights of custody, thereby making a removal wrongful. Re H, [1990] 2 Fam. L. Rep. 439 (Eng. Fam. Jan. 16, 1990). The English court stated, "There is nothing . . . in Art. 3 which indicates . . . that the breach of the rights of custody has to be a breach of the rights belonging to some other person." Id.

60. The court also noted that under Articles 18 and 21 of the Convention, a court has discretion to order children returned to their habitual residence for the purpose of visitation. Viragh, 612 N.E.2d at 247 . Here, where there was evidence based on prior behavior that the children would not be returned after visitation, the refusal to order that the children be returned for visitation was appropriate. Id.

61. S. v. A., [1992] 89 D.L.R.(4th) 204 (B.C. C.A. Feb. 14, 1992), reversing [1990] 65 D.L.R.(4th) 222 (B.C. Super. Ct. Jan. 5, 1990). 
care of a child while he was living in Germany, did not have "custody rights" under German law and thus the natural mother was free to take the child from Germany to the United States without violating the provisions of the Hague Convention. ${ }^{62}$ Thus, the German foster parents did not have a basis to seek return of the child from New Jersey, where the child was in the care of the maternal grandparents.

As noted earlier, an important and significant aspect of the Hague Convention-unlike other international treaties on child custody-is its application to pre-decree situations. Many abduction situations occur before any formal legal action is ever started. Thus, at the first signs of a disintegrating family situation, one parent may decide to take the children off to another country, particularly where that parent is returning to a home country. ${ }^{63}$ To the extent that countries seem to treat the custody rights of a married couple as joint, unilateral action by one party in taking a child to another country or preventing the return to the place of habitual residence will amount to a breach of custody rights under the Convention. For example, in Becker v. Becker ${ }^{64}$ the court found that the husband, who had taken his children on a trip to the United States from the family's home in Australia and refused to return, wrongfully retained the children. The wife brought an action in New Jersey under the Hague Convention for return of the children, and a return order was granted.

Rights of unwed parents may present a special situation. In the case of $R e$ $J .,{ }^{65}$ the English House of Lords dismissed an appeal and refused to order return of a child taken by an unmarried mother from Western Australia to England. The court found that under Western Australia law an unmarried mother has exclusive rights to her child unless a court expressly confers rights on the father. Interestingly, the father subsequently obtained custody rights in Australia and then argued that the child was being wrongfully retained in England. The House of Lords found no wrongful retention in that the order conferring custody rights on the father had come too late since by this time, the mother had "unilaterally" terminated Western Australia as the habitual residence. The House of Lords concluded that England, and not Australia, was

62. Loos v. Gross, No. FD-20-00031-94 (N.J. Super. Ct., Union Cty., May 6, 1994) (on file with author).

63. According to the PÉREZ-VERA REPORT,

one cannot forget that, in terms of statistics, the number of cases in which a child is removed prior to a decision on its custody are quite frequent. Moreover, the possibility of the dispossessed parent being able to recover the child in such circumstances, except within the Convention's framework, is practically non-existent, unless he in his turn resorts to force, a course of action which is always harmful to the child. In this respect, by including such cases within its scope, the Convention has taken a significant step toward resolving the real problems which in the past largely escaped the control of the traditional mechanisms of private international law.

PÉREZ-VERA REPORT, supra note 2, at 446.

64. 15 Fam. L. Rep. (BNA) 1605 (N.J. Super. Ct., Morris Cty., Aug. 28, 1989).

65. [1990] 2 All E.R. 961 (Eng. House of Lords July 26, 1990). For additional discussion of this case, see Bruch, International Child Abduction Cases, supra note 23, at 355-56. 
the proper forum to determine custody rights under English law. Like several other cases, the decision in the House of Lords may have achieved a correct result, but its reasoning seems flawed. As the Treaty history reveals, habitual residence is less a legal construct than a factual one. More than likely, the House of Lords was attempting to limit the impact of post-removal decrees in affecting "custody rights," particularly in the context of situations where one parent does have the right to move with the child. Such post-removal efforts to secure custody rights for the first time should not give rise to a finding of "wrongful retention" in any event, and the decision should have rested on that basis.

An issue that arises less frequently is the type of conduct that evidences a wrongful retention. In one case, for example, an Israeli family had taken a sabbatical year in England; the marriage broke up and prior to the end of the year period, the mother announced she did not intend to return the children to Israel. ${ }^{66}$ The court held that under the circumstances the mother's action constituted a "wrongful retention," notwithstanding the original arrangement to be in England for the year. ${ }^{67}$

\section{B. How To Ascertain "Custody Rights"}

The inquiry into "custody rights" is linked to the concept of "habitual residence" since it is the "law" of the country of habitual residence that is looked to in order to ascertain those rights. ${ }^{68}$ The last paragraph in Article 3 explains that rights of custody may arise in three ways: by operation of law, by reason of a judicial or administrative decision, or by reason of an agreement having legal effect under the law of that state.

The reference to the "laws" of the state in which the child was habitually resident, and not the more traditional "internal law" concept of other Hague Conventions, was quite deliberate. ${ }^{69}$ The Convention's intent is to safeguard those relationships that are protected by virtue of the law of the state where the child's relationships developed prior to removal. ${ }^{70}$ In the usual case, the internal custody law of the state of habitual residence will likely define the "custody rights" of the parties, irrespective of their nationality, when the parents also reside in that country with their children. In some circumstances, however, the law of the state of habitual residence may refer to another law-such as the law of the state of the parents' nationality-as a matter of its conflict of laws rules. The Convention permits the state of habitual residence to make that choice. ${ }^{71}$

66. Re S, [1994] 1 All E.R. 237 (Eng. Fam. July 14, 1993).

67. Id.

68. Hague Convention, supra note 1, art. 3a, S. TREATY Doc. No. 11 at 7, 19 I.L.M. at 1501.

69. A proposal to include a reference to the rules of private international law in the treaty text was rejected, but the treaty history makes clear that the Conference thought the inclusion unnecessary and did not reject the concept. PÉREZ-VERA REPORT, supra note 2, at 445-56.

70. Id. at 446 .

71. The following example is noted in the Convention's Explanatory Report: French father of a child born out of wedlock removes the child to France from its habitual residence in Spain, where the 
As noted earlier, the custody rights that arise by operation of law include rights that exist prior to any formal decision about custody. The Convention seems to assume that such pre-decree rights do exist, and, in most cases, such rights to custody reside in both parents, at least where the parties are married. Several court decisions interpreting the Convention bear out this assumption, ${ }^{72}$ although we may see more debate about this subject in the future. In several of the cases, the judicial authorities have taken judicial notice of such preexisting custody rights, as they are permitted to do under Article 14 of the Convention. In some situations, a "decision" or "other determination" of a breach of custody rights from the state of habitual residence may be requested by the requested state, as authorized by Article $15^{73}$

In the United States, there may be some doubt as to whether a parent who leaves the country and fails to return has in fact breached the other parent's "custody rights." Only if the concept of pre-decree "custody rights" incorporates

child lived with its French mother. Under the custody law of France, the mother would have "custody rights" but not under Spanish rules. As a matter of conflicts law, however, Spain would apply the law of nationality to questions of custody, and therefore the removal would be in breach of the custody rights of the "law of habitual residence" as that term is used in the Convention. Id.

72. See, e.g., Dickson v. Dickson, 1990 S.C.L.R. 692 (Ct. Sess., Inner House, June 8, 1990) (Scot.) (Australian parents share joint custody of child under age of 18); Re F, [1992] 1 Fam. L. Rep. 548 (Eng. C.A. July 31, 1991) (parents share right of joint custody and guardianship under Australian law); Re RPW, 1992 No. 106SP (Ir. High Ct. Feb. 19, 1992) (transcript) (LeXIS, Irelnd library, Cases file) (under English law, parents share joint parental responsibility over minor child); Whitley v. Whitley, 1992 Inner House Cas. (Scot. Apr. 29, 1992) (under Virginia state law, parents are joint natural guardians and thus share in custody of minor child); Judgment of Feb. 13, 1992 (Korowin v. Korowin), No. 138036, Bezirksgericht (Dist. Ct.) des Kanton Horgen (Switz.) (married parties have joint custody under Michigan law) (available on Hilton BBS). The rights of an unwed biological father may be more complicated. See Re J., [1990] 2 All E.R. 961 (Eng. House of Lords July 26, 1990) (discussed in text accompanying note 65); S v. M, 50 R.F.L.(3d) 59 (Alberta C.A. 1993) (unwed father could only apply for rights of custody). For a discussion of the Convention when there is no pre-event custody order, see Carol S. Bruch, Child Abduction and the English Courts, in Frontiers OF FAMILY LAW 62, 67-73 (Andrew Bainham \& David S. Pearl eds., 1993).

73. Article 15 provides: "The judicial or administrative authorities of a Contracting State may, prior to the making of an order for the return of the child, request that the applicant obtain from the authorities of the State of the habitual residence of the child a decision or other determination that the removal or retention was wrongful within the meaning of Article 3 of the Convention, where such a decision may be obtained in that State." See also Article 7(e) (directing Central Authorities to provide information of a general character as to the law of their State in connection with application of the Convention) and Article 8(f) (providing that an application may be accompanied or supplemented by a certificate or affidavit from a Central Authority or other competent authority regarding the relevant law). Hague Convention, supra note 1, art. 15, S. TrEATY Doc. No. 11 at 10, 19 I.L.M. at 1503 . Even if not requested, it may be desirable for an applicant to obtain a ruling from the courts in the State of habitual residence that the other party has interfered with or violated the applicant's custody rights under the applicable law and to introduce it in the Hague Convention proceeding. Although the foreign custody orders are not necessarily binding, they are often relevant evidence on the issue of what the existing "custody rights" were at the time of removal or retention. In addition, the initiation of such proceedings is often evidence relied upon to negate any inference of acquiescence. See, e.g., Wanninger v. Wanninger, 850 F. Supp. 78 (D.C. Mass. 1994) (German husband whose wife wrongfully retained children in United States first sought relief in German Family Court that children had been wrongfully retained in violation of Hague Convention, and then petitioned U.S. federal court for order of return under the Convention); Currier v. Currier, 845 F. Supp. 916 (D.N.H. 1994) (German wife whose husband took children to the United States brought both criminal and civil proceedings in Germany and obtained ruling from German courts that removal was wrongful). See generally Silberman, Hague Convention on International Child Abduction, supra note 9, at 20. 
a restriction on unilaterally changing the domicile or residence of the child has there been a wrongful removal and/or retention. In Korowin v. Korowin, a Swiss court, on the basis of submissions from the U.S. Central Authority, ruled that the mother had breached the father's custody rights when she took the child from Michigan to Switzerland and failed to return. The Swiss court relied upon representations by U.S. State Department consular officers and a Swiss official that in such a pre-decree situation "under American law in the State of Michigan, [the parties] had joint custody." 74 Finding it irrelevant that the mother may have been the de facto caregiver, the court determined that there was a "breach of custody rights" when she unilaterally took and failed to return the child. ${ }^{75}$ Clearly, this aspect of Korowin effectuates the objectives of the Convention and is consistent with its intent. At the same time, however, the Convention's concept of pre-decree custody rights does not always have clear analogues under domestic law. Under the Convention, contracting states must determine whether a particular state has conferred "custody rights" within the Convention's meaning. When the United States is the habitual residence, requests for pre-decree returns to the United States may create some uncertainty, since the states have not always defined custody rights in the absence of a decree. In situations where a parent is granted custody pursuant to a court decree, the custodial parent may or may not have the right to relocate with the child. In one English case, $C$ v. $C{ }^{76}$ the court was. required to determine whether the removal of children from New York to England by the custodial parent was wrongful because of an implicit limitation in removing children to a distant locality imposed by the New York case law. ${ }^{77}$ In interpreting New York law with the aid of expert affidavits by several New York lawyers, the court concluded that the mother could not remove the children without applying for permission, and therefore the father's custody rights had been violated. ${ }^{78}$ It made no difference, held the court, whether there was an express prohibition on removal contained in an order or one that was implied by settled case law. ${ }^{79}$

One lesson to be derived from experience with the Convention is that domestic law may need to be buttressed to ensure effectiveness of the treaty when children are taken from a habitual residence in the United States. Not only would such legislation clarify the issue of custody rights with respect to the Hague Convention but it also would set out quite specifically the custodial rights of parents for domestic law purposes in the absence of a decree. ${ }^{80}$

74. Judgment of Feb. 13, 1992 (Korowin v. Korowin), No. 138036, Bezirksgericht (Dist. Ct.) des Kanton Horgen (Switz.) (available on Hilton BBS).

75. Id.

76. [1992] 1 Fam. L. Rep. 163 (Eng. Fam. Aug. 21, 1991).

77. Id.

78. Ultimately, the father decided not to seek return of the children and instead sought orders of access both within and outside England. Id.

79. Id.

80. By and large within the United States, pre-decree rights have not been recognized in either the criminal or tort context. Thus, misdemeanors and felonies for custodial interference usually require a violation of a custody order. See, e.g., ALA. CODE $\$ 12-15-14$ (1992); REV. STAT. Mo. $\$ 565.150(1)$ 
A second way custody rights can be established is by reason of judicial or administrative decision. ${ }^{81}$ As the treaty history makes clear, the decision may be that of the state of habitual residence or one of a third country accepted by the state of habitual residence. It is unnecessary that there be formal recognition of a third country's decree; it is sufficient that the decree "contain in principle certain minimum characteristics which are necessary for setting in motion the means by which it may be confirmed or recognized." 82

Finally, agreements about custody which have legal effect in the state of habitual residence are also a source of custody rights under the Convention. ${ }^{83}$ Such legal effect may be the result of the internal law of the state of habitual residence or of its choice of law rules. ${ }^{84}$

\section{What Constitutes "Habitual Residence"}

As noted above, identifying the state of habitual residence is critical. The relevant custody rights are those recognized by the state of habitual residence, and it is the state of habitual residence to which the child should be returned and where the ultimate merits of custody are to be decided. "Habitual residence" is a "well-established concept in the Hague Conference, which regards it as a question of pure fact, differing in that respect from domicile." 85 Indeed, the Convention is true to this conviction and does not offer a definition of habitual residence. In some cases, the determination of "habitual residence" is relatively straightforward, but in others, the issue may be more complicated than it first appears. An easy case is Tyszka $v$. Tyszka, ${ }^{86}$ where children who were taken by their father to Michigan from France and retained there over the mother's objection were found to be "habitually resident" in France and ordered returned there. More complicated may be Meredith v. Meredith, ${ }^{87}$ involving a family

(1991); N.Y. v. McDonald, 554 N.Y.S.2d 394 (N.Y. Cty. Ct., Fulton Cty., 1990) (dismissing criminal indictment under New York custodial interference statute where no custody order existed prior to parent's taking of child from other parent). But compare WIS. STAT. § 948.31(3)(a) (1991-92) (absent an affirmative defense, parent who intentionally conceals child from the other parent is guilty of felony). Similarly, tort claims are usually recognized only when a court order has been violated. See, e.g., Nwankwo v. Nwankwo, No. 92-1624, 1992 U.S. App. LexiS 32222 (1st Cir. Dec. 9, 1992) (legal impossibility for plaintiff to succeed on state law claim for custodial interference where no custody decree in his favor at time other parent took child). Although a few states expressly provide that parents share in the joint custody of a minor child as a general matter, see, e.g., KY. REV. STAT. ANN. $\$ 405.020$ (1993) ("father and mother shall have the joint custody" of the minor child) and CAL. CIV. CODE $\$ 197$ (1993) (father equally entitled to the custody, services, and earnings of minor child), whether and how such general pre-decree rights translate into enforceable rights is unclear. See also Children Act, 1992, ch. $41, \S 2$ (U.K.), 6 Halsbury 4th 387, 393 (1992) (where parents are married, both share parental responsibility for minor child).

81. Hague Convention, supra note 1, art. 3b, S. TREATY DoC. No. 11 at 7, 19 I.L.M. at 1501.

82. PEREZ-VERA REPORT, supra note 2, at 447.

83. Id. at 437 .

84. Id.

85. Id. at 445 .

86. No. 90-022578-DM (Mich. Cir. Ct., Wayne Cty., Feb. 21, 1991, ) (available on Hilton BBS). See also 503 N.W.2d 762 (Mich. Ct. App. 1993) (vacating trial court's subsequent award of joint custody on the ground that issue of custody is for French court once return has been ordered).

87. 759 F. Supp. 1432 (D. Ariz. 1991) 
living in Arizona. The wife took the child on a visit to France and did not return. After some difficulty, the father finally located the child in England and brought the child to Arizona. The father had obtained a custody award in Arizona shortly after the mother departed; the mother had brought proceedings in England to establish custody. The mother then commenced an action for return of the child in the federal district court of Arizona. The court refused to order return of the child to England, determining that Arizona, not France or England, was the child's habitual residence. Thus, Arizona was the appropriate forum for litigation of the custody issues between the parties. This case may be one which the statistics will count as a "denial" of return, thereby suggesting an "unfavorable" Convention outcome, but a closer look indicates that the case is correctly decided within the spirit of the Convention. The parents and the child had been living in Arizona; it was the unilateral action of the mother in taking the child from Arizona and failing to return which first constituted "wrongful" conduct under the Convention. Of course, the father's "proper" action would have been to commence a Hague proceeding in France or England, where the child was taken. If those countries properly interpreted the Convention, the child would have been returned to Arizona for custody proceedings. In Meredith, however, the father took matters into his own hands and "reabducted" the child back to Arizona. It is in this sense that the Convention may not necessarily deter abductions and in some instances might even encourage a selfhelp remedy. It should be remembered, of course, that the only issue being decided in Meredith (and all other Hague Convention cases) is which forum is appropriate for the litigation of the custody issue. The decision concerning return has no bearing on who ultimately is entitled to custody of the child. ${ }^{88}$

Resort to the Hague Convention in France or England might have been the more appropriate remedy by the father in the Meredith case, but such route will be taken only if other countries are vigilant in their own enforcement of the Convention. While there are Convention cases in those countries to indicate that a Hague proceeding in France or England would have also resulted in return of the child to Arizona, it is also possible that an English or French court might have resolved the habitual residence issue differently under the circumstances or found some defense to the "return" issue. As Meredith indicates, the determination of which state is the "habitual residence" is often decisive, and if inappropriately interpreted, will circumvent the Convention's goal. An example of such misinterpretation comes from dicta in an American case, In re Marriage of Collopy. ${ }^{89}$ A Greek man and a Colorado woman met abroad, went to Colorado to get married, and returned to England to allow the husband to attend school there. Shortly after the birth of their child, the wife returned to the United States. After several months, the father objected to the child remaining in

88. "A decision under this Convention concerning the return of the child shall not be taken to be a determination on the merits of any custody issue." Hague Convention, supra note 1, art. 19, S. TREATY DOC. No. 11 at 11,19 I.L.M. at 1503.

89. No. 90 DR 1138 (Col. Dist. Ct., Div. B., Adams Cty., May 8, 1991) (available on Hilton BBS). 
Colorado with the mother, but did not bring his Hague petition for return of the child until more than one year had elapsed. Because the child had been in the United States for more than one year, the court exercised its discretion under Article 12 not to return the child because it was "now settled in its new environment." On the issue of habitual residence, however, the court held that England was the habitual residence of the child "because it was the habitual residence of the father." Such reasoning seems flawed. The Convention expressly rejected adoption of the formal technicalities of "domicile," which ordinarily would impute the domicile of the father to the minor child.90 England may well be the child's habitual residence, but if so, it is because England is where the child had lived with both its parents prior to the temporary visit to Colorado and wrongful retention there.

A second unfortunate interpretation was avoided when the Sixth Circuit Court of Appeals in Friedrich v. Friedrich ${ }^{91}$ reversed a district court's misreading of "habitual residence" and emphasized the importance of defining the concept within the aims of the Convention. In Friedrich, the American mother, a member of the United States Army, and her German husband had been living off-base in Germany with their son. Following a serious argument, the husband ordered the wife to leave the house with their son. Shortly thereafter, the mother took the son and went to Ohio to live with her parents, returning to Germany briefly to seek discharge from the Army. In the interim, the father had secured a temporary custody order in Germany, granting him custody, while the mother had obtained a similar order in her favor in Ohio. Thereafter, the father brought a Hague custody proceeding in Ohio, seeking return of the child. The district court refused to return the child. The lower court ruled that because the father's behavior had forced the mother to obtain temporary housing on the army base, the child's habitual residence "instantly" became the United States." As a result, the United States was the habitual residence, and relief to the father under the Convention was unavailable. The U.S. Court of Appeals for the Sixth Circuit reversed the district court. The appeals court took great care to distinguish the Convention's concept of habitual residence from the more traditional definition of "domicile." 93 More fundamentally, it noted that "habitual residence" was not to be predicated on the care or protection of a particular parent:

[h]abitual residence can be "altered" only by a change in geography and the passage of time, not by changes in parental affection and responsibility. The

90. Cf. RESTATEMENT (SECOND) OF CONFLiCT OF LAws $\$ 14$ (1971). The domicile of a legitimate child at birth is that of the father. Where a separation or divorce occurs, a child takes the domicile of the parent to whom custody has been given or with whom the child lives.

91. 983 F.2d 1396 (6th Cir. 1993).

92. Friedrich v. Friedrich, C-1-91-651 (S.D. Ohio 1992) (available on Hilton BBS).

93. See also Re B, [1993] 1 Fam. L. Rep. 993 (Eng. Fam. Aug. 21, 1992) (habitual residence is essentially different from domicile and requires a much less wide-ranging inquiry). 
change in geography must occur before the questionable removal; here, the removal precipitated the change in geography.

The dual abduction scenario has also put pressure on identification of habitual residence. In Tahan v. Duquette, ${ }^{95}$ an initial New Jersey decree had given a New Jersey father and a Canadian mother alternating custody, but the mother refused to return the child after a visit in Canada. The father's attempt to enforce the New Jersey order in Canada-the Hague Convention was not in effect at the time-was converted into a full custody hearing and the mother obtained custody and the father visitation. When the father then refused to return the child from a visit in New Jersey, the mother sued in New Jersey under the Convention for return of the child. Among the father's arguments was the claim that the child's habitual residence was New Jersey, since New Jersey was the place where the child had spent most of his life. The appellate court determined that the child was "habitually resident" in Canada, and in a colloquy with counsel during a hearing on remand, ${ }^{96}$ the trial judge observed:

\begin{abstract}
Habitual residence in this case is Canada. The habitual residence is established by somebody being awarded custody or by somebody being entitled to custody even without an order for custody. The custody order in this case is from a Canadian court, and that by definition makes the habitual residence in this instance Canada. ${ }^{97}$
\end{abstract}

Contrary to that rationale, the existence of a custody order does not determine habitual residence. ${ }^{98}$ Had the father initially been able to seek return under the Convention, New Jersey would most likely have been viewed as the habitual residence. And had the father not participated in the Canadian proceedings, it is unlikely that a Canadian court's custody decree would have transformed

94. Friedrich, 983 F.2d at 1402. Judge Lambros (sitting by designation) dissented, arguing that, in expelling the child from the apartment, the father gave up any right of custody. Id. at 1404 .

95. 613 A.2d 486 (N.J. Super. Ct. App. Div. 1992); 600 A.2d 472 (N.J. Super. Ct. App. Div. 1991).

96. Tahan v. Duquette, No. A-2023-90 T3 (N.J. Super. Ct. Ch. Div, Camden Cty., June 24, 1992) (transcript of proceedings; available on Hilton BBS).

97. Id.; see also Duquette v. Tahan, 600 A.2d 472, 476 (N.J. Super. Ct. App. Div. 1992).

98. The error of equating a custody order with a determination of habitual residence has been made by other courts. The Decision of the Children's Judge at 's-Hertogenbosch District Court, the Netherlands, February 13, 1991 (on file with author), found that a wife who unilaterally went to England with the child and sought relief in the English courts had established habitual residence in England. At least one state appellate court in the United States, Crommelin-Monnier v. Monnier, 638 So.2d 912 (Ala Civ. App. 1994), has created additional confusion by ignoring the requirements of the Convention and the concept of habitual residence because it found that the applicant on a return petition was subject to the court's in personam jurisdiction. The appellate court reversed the trial court's order of return, stating that "[w]ith the Alabama courts having in personam jurisdiction over the father as well as the minor children in this divorce and custody case, we hold that the father's Hague Convention petition was due to be denied." The court's personal jurisdiction over the father should be irrelevant to the question of whether an action under the Convention is appropriate, and in any event the Hague Convention takes precedence over inconsistent state law. The Monnier case actually presented an interesting "habitual residence" issue-not discussed in Convention terms by the court-because although the family had lived primarily in France, the mother continued to maintain her residence in Alabama and came back to Alabama for the birth of the children and stayed in Alabama for a period of time after each birth. 
Canada into the habitual residence. But once the parties adjudicated the custody issues in Canada and the mother took custody of the child there, albeit for a short period, the determination that Canada was the habitual residence was understandable and consistent with the spirit of the Convention. Nonetheless, looked at from the inception of the marital breakdown, the habitual residence would appear to be New Jersey, not Canada.

One common scenario unfolds where the parents (or one of them) make various geographical moves, sometimes with the child, in the midst of a disintegrating marriage. Often, one party claims a move is "temporary" or a "holiday," and the other insists the move is more permanent. For example, in Levesque v. Levesque, ${ }^{99}$ a couple residing in Germany had joint custody of their daughter under a separation agreement. The parties reconciled for a period in the United States, after which the mother and child, with the father's permission, returned to Germany, although there was conflicting testimony as to whether that return was to be temporary or permanent. When the mother indicated the marriage was at an end, the father abducted the child to Kansas. In resisting a Convention action for return by the mother, the father argued that Kansas-where the parties had lived briefly together-was the habitual residence, and therefore return was not appropriate. The court did not believe that it had to resolve the conflicting versions about whether the mother's return to Germany was temporary or permanent because both parties had agreed that the mother could return to Germany with the child for "some period of time." 100 According to the court, on the return to Germany there was by mutual agreement "an intent to remain, at least for a period of time which was indefinite." The court relied upon an earlier English case, Re Bates, ${ }^{101}$ which emphasized the "fluid and fact-based" nature of the concept of habitual residence and stressed the importance of finding a sufficient degree of continuity of living to properly be described as "settled."

In another case, an English court did find it necessary to resolve conflicting testimony about the nature of the move. In $\operatorname{Re} F,{ }^{102}$ the Court of Appeal dismissed a father's appeal of the lower court's return order, holding that the lower court had properly resolved the conflicting versions of a family's move from England to Australia and subsequent return to England by the father with the child. Some months after a relocation to Australia, the father returned with the child to England. According to the English father, the family had traveled to Australia for an extended holiday, during which time the parents were to consider whether to live in Australia for a longer period of time. According to the Australian mother, however, the intention of both parents was a permanent

99. 816 F. Supp. 662 (D. Kan. 1993).

100. See also Dickson v. Dickson, 1990 S.C.L.R. 692 (Ct. Sess., Inner House, June 8, 1990) (Scot.) (child's leaving of habitual residence with consent of parent constitutes abandonment of that habitual residence).

101. No. CA 122/89 (Eng. Fam. Feb. 23, 1989) (available on Hilton BBS).

102. [1992] 1 Fam. L. Rep. 548 (Eng. C.A. July 31, 1991). 
move to Australia. The court agreed with the mother and held that the child's habitual residence was Australia. ${ }^{103}$ In reaching its conclusion, the court considered documentary evidence such as the shipment of nineteen packing cases to Australia, the father's Australian visa application and partial completion of resident status application forms, letters between the wife and her Australian relatives preceding the move, and the parents' application for an Australian distributorship. The English Court of Appeal held that since no oral testimony was offered, the lower court properly relied on these facts in determining that Australia was the child's habitual residence, ${ }^{104}$ it found the evidence compelling and the father's affidavit improbable. In addition, the Court of Appeal observed that the Convention's success requires "that a child should have, where possible, an habitual residence, otherwise he cannot be protected [from] abduction by a parent from the country where he was last residing."

Another recent case uncharacteristically incorporated notions of fault into the "habitual residence" inquiry. In In re Ponath, ${ }^{105}$ a German father and American mother who lived in Utah moved to Germany, where the father found employment and began construction of a house. After a short time, the mother wanted to return to the United States, but the husband resisted. Almost a year later, the mother did return to Utah with the child. When the husband brought his Hague petition for return in Utah, the court refused to order return, holding that Utah and not Germany was the state of habitual residence. The court found that the wife's continued residence in Germany was "coerced," negating the possibility of finding that the extended visit had matured into a settled residence. Although it is the habitual residence of the child that is relevant, the court held that it could not ignore the desires and actions of the parents. In the court's view, "the concept of habitual residence must entail some element of voluntariness and purposeful design." ${ }^{106}$ However, a later case, In re Prevot, ${ }^{107}$ refused to extend the coercion concept of Ponath to a situation where a family had moved from Tennessee to France, and the wife, after a year of living in France, wanted to return to the United States but the husband had confiscated the passports. When the mother eventually managed to return to Tennessee with the children, the father brought a Convention action for return. The court ordered the children returned to France and rejected the wife's contention that her stay in France was "coerced." In fact, held the court, only after the parties had lived in France for a substantial time did marital difficulties between the parties develop.

103. In the alternative, the court held that the father had acquiesced in the child remaining with the mother, who had at all times intended to reside in Australia permanently . Id.

104. On the acquiescence issue, however, the Court of Appeal disagreed with the lower court; where there is a short period and the parents have not finally parted, the absence of legal action should not be taken as acquiescence. Id.

105. 829 F. Supp. 363 (D. Utah 1993).

106. Id. at 367 .

107. No. Misc 93-61-M1, 1994 U.S. Dist. LEXIS 8190 (W.D. Tenn. 1994). 
One last variation on the "habitual residence" issue results when a parent consents to a change of custody to the other parent, for at least some period, and then demands return of the child. Such a case was presented in Slagenweit v. Slagenweit, ${ }^{108}$ where the American father left his home in Germany during marital difficulties with his German wife and came to the United States. Both parents agreed that one of the children, a disabled daughter, should live with the husband in Iowa, at least temporarily, because of the excellent medical facilities there. The father later refused to return the child, and the mother sought relief in federal court under the Convention. The court stated that if Germany continued to be considered the child's habitual residence, there was no wrongful retention until the noncustodial parent objected to the child's stay in Iowa. Since the mother's Hague petition was filed well within a year from the time she first requested return of her daughter, ${ }^{109}$ the father's Article 12 defense-that proceedings had not been brought within a year and the child was now settled in a new environment-would fail. Nonetheless, the court refused to order return, holding that the habitual residence of the daughter changed from Germany to Iowa as a result of her substantial involvement in the community in which she was living with the consent of both parents. The combination of a geographical change in the child's living conditions with the mutual assent of both parents, and a substantial passage of time altered the habitual residence from Germany to Iowa. The court explained:

In those cases where the child has become so settled in her new environment by mutual agreement of the parties, prior to the assertion of custodial rights, then the case should be analyzed under the question of whether a new habitual residency has been established for the child. In most cases, such as this, when there is a change of custody from one parent to the other by consent, followed by a demand for return of the child, the parent demanding the return will have a difficult time showing that the voluntary change of place of residence did not also result in a change of habitual residency. ${ }^{110}$

These various cases illustrate the importance of both the construct of habitual residence that is adopted by Convention countries and the fact-finding that is engaged in by the courts on this issue. Note that when a parent takes a child from one state to another, there is no requirement of return if the new state qualifies as that of habitual residence. Conversely, an "abduction" back to the habitual residence also fails to trigger a return order. ${ }^{111}$ Thus, the core concept of the Convention will be preserved only if unilateral moves by one parent are resisted in giving shape to the concept of "habitual residence."

108. 841 F. Supp. 264 (N.D. Iowa 1993).

109. The daughter had in fact resided with her father in Iowa for more than a year before the filing of the Hague petition, but that custodial arrangement was with the consent of both parents.

110. Slagenweit, $841 \mathrm{~F}$. Supp. at 270.

111. See, e.g., Cohen v. Cohen, 602 N.Y.S.2d 994 (N.Y. Sup. Ct., Kings Cty, 1993) (no mutual intent of both parties to move to Israel from the United States; thus, mother who "abducted" children from their father in Israel and brought them back to the United States not subject to return order because Israel was not "habitual residence"); Meredith v. Meredith, 759 F. Supp. 1432 (D. Ariz. 1991), discussed supra at text accompanying notes 87-88. 


\section{The Problem of Retroactivity}

Although Article 35 of the Convention limits the application of the Convention to "wrongful removals or retentions occurring after its entry into force" in contracting states, some applicants had argued that a wrongful retention is a "continuing offense" such that an order for return could still be granted once the Convention became effective between contracting states. In a leading case on this point, Kilgour v. Kilgour, ${ }^{112}$ a Scottish court rejected this argument. The Convention had entered into force between the United Kingdom and Ontario "on or after" August 1, 1986. The mother wrongfully took the child from Canada to Scotland in January 1986, prior to the effective date of the Convention. Following the removal, the Canadian court made several interim custody orders in favor of the father and granted him custody on a final basis on August 25, 1986. On the husband's application for return filed in Scotland, the father argued that there had been a "continuing wrongful retention" after the effective date of the Convention and, in addition, that a second wrongful retention occurred once the Canadian court gave him permanent custody. Acknowledging that the "continuing offense" concept was a plausible one, the court found more convincing the interpretation that the Convention envisaged removals or retentions occurring on a specific date in order that an effective date of the treaty could be measured. In addition, the court did not think that a change from an interim to a permanent decree should create a new "retention," noting that such an interpretation would also create problems with respect to the one-year limitation period after which a child need not be returned. ${ }^{13}$

A similar view of the retroactivity issue was offered-albeit through a different rationale -in an Australian case, Gollogly v. Owen. ${ }^{114}$ In this action, the children had been taken from Alaska and brought to Australia prior to the effective date of the Convention in the United States. After the treaty had entered into force between Australia and the United States, the Alaskan court granted custody of the children to the father. The father argued that the retention of the children in Australia by the mother became wrongful after the Alaskan court rendered its court order. The Australian court concluded that removal or retention was wrongful only where it was in breach of custody rights under the law of the state of habitual residence, and Alaska, which gave the father "custody rights," was held not to be the state of habitual residence since the mother and children had been living in Australia for a settled period. In effect, the rationale in Gollogly prevents retroactive application of the Conven-

112. 1987 Sess. Cas. 55 (Ct. Sess., Outer House, Dec. 24, 1986) (Scot.).

113. See also Re H; Re S, [1991] 3 All E.R. 230 (Eng. House of Lords June 13, 1991) (where children removed from state of habitual residence prior to such state becoming a contracting state, Convention did not apply).

114. 13 Fam. L. Rep. 622 (Austl. Fam. Ct., Townsville, Oct. 5, 1989) (available on Hilton BBS). 
tion. Some courts, however, have applied the principles of the Convention even when it technically does not apply and ordered the return of children. ${ }^{115}$

\section{E. The Defenses}

As noted earlier, the defenses to the Convention are limited but do allow for return to be avoided in the case of "acquiescence," "grave risk of harm" or creation of an "intolerable situation," or a violation of "fundamental human rights." Note that the court retains discretion to order return even if one of the defenses applies. In addition, a set of time limits as well as objections by mature children may affect whether or not return is ordered.

Perhaps the most important aspect for success of the Convention will be the ability to limit the use of defenses. If the Convention procedures result in return of the child for a custody determination, parties will be encouraged to invoke them. But if certain contracting states rely on the defenses to avoid return, the return mechanism will be thwarted. International cooperation will be frustrated, and parties will once again resort to self-help. Two recent cases in the United States reflect a policy consistent with the sense of the Convention to interpret the exception narrowly. In Wanninger $v$. Wanninger, ${ }^{116}$ the federal court rejected an acquiescence defense by a mother who had failed to return her children to Germany after bringing them to the United States. As the parents attempted to work out their marital difficulties, the father had agreed the children could stay with their mother for a time in the United States, and the mother contended that this conduct amounted to acquiescence. The court rejected the argument, noting that the father had not acquiesced to the children's permanent residence in the United States once he realized the marriage was irreconcilable. The second case, Currier v. Currier, ${ }^{117}$ involved a more complicated scenario. After various separations and reconciliations by a couple living in Germany, the wife signed an agreement, mooting an earlier custody order in the wife's favor and granting her husband sole custody of the children. When the wife immediately sought to revoke the agreement and obtained an order from the German court that the children be turned over to her, the husband left Germany with the children for the United States. On the wife's Hague petition for return, the U.S. court rejected the husband's contention that the wife had acquiesced to his control over the children. To the contrary, the court noted, the wife's conduct was consistent with her claim for custody: she rescinded the agreement before the children were removed from Germany; she brought proceedings in Germany, both civil and criminal, and she promptly sought an order of return under the Convention.

115. See, e.g., Re F, [1990] 3 All E.R. 97 (Eng. C.A. July 30, 1990) (ordering return of child to Israel despite the fact that Israel was not a party to the Convention at the time of wrongful removal).

116. 850 F. Supp. 78 (D. Mass. 1994).

117. 845 F. Supp. 918 (D. N.H. 1994). 
Decisions in other countries have more mixed results. Several lower courts in France had adopted broad interpretations of "acquiescence" to avoid return, until the highest court in France, the Cour de Cassation, rendered an important decision requiring that there be an intention "sans equivoque et de façon certaine" in order to establish acquiescence. ${ }^{118}$ In one early case, Aubry v. Aubry, ${ }^{119}$ both the Court of Higher Instance and the Paris Court of Appeals found acquiescence by an English father whose French wife had taken the children for a family visit to France from their home in New York and then failed to return. Mrs. Aubry argued that the father's conversations and actions while on a later visit to France evidenced his consent to have the children remain in France with her. The evidence relied upon by the courts consisted of the testimony of Mrs. Aubry's family and the fact that Mr. Aubry visited private schools in France with respect to his son's education. While the court's finding of "acquiescence" is not implausible, it is more likely-given the set of events - that the parties had tried unsuccessfully to negotiate a settlement under which the children would stay in France with their mother. There are two unfortunate by-products of a case like Aubry. First, the outcome is likely to be viewed as French favoritism toward its own citizens and a reluctance to enforce the Convention in this situation. Such a perception might induce a party in Mr. Aubry's situation to attempt to take the children back by whatever means and have the issue of habitual residence litigated in an American court, as in Meredith. Second, to the extent that a court translates "negotiations" into "acquiescence," counsel will advise their clients to bring formal proceedings and refuse to talk or negotiate at all. Fortunately, the later opinion of the Cour de Cassation in the Horlander case helps to dispel the fears created by Aubry and the lower court versions of Horlander. In Horlander, the French mother took the children to France from their habitual residence in Indiana. Mr. Horlander's offer of an overall custody and property settlement had been construed by the same courts that decided Aubry to constitute "acquiescence." But the Cour de Cassation held that Mr. Horlander's attempt to reach an amiable solution with his wife was not an unequivocal act of acquiescence. ${ }^{120}$

Several English cases have also explored the parameters of the "acquiescence" defense with conflicting results. In one case, $R e A$ and Another, ${ }^{121}$ the English Court of Appeal approved a lower court ruling, which rejected the acquiescence defense and ordered return where a mother wrongfully retained the children on a visit in England from their home in Arizona. Although the father came to visit in England and told the mother that he would not remove the children and only wanted his rights defined, his subsequent actions of filing for

118. See Judgment of July 16, 1992 (Horlander v. Horlander), Cass. Civ., 1992 Bull. Civ. L. No. 9118177 (Fr.) (on file with author).

119. Judgment of Dec. 5, 1990 (Aubry v. Aubry), Trib. gr. inst. de Paris (Fr.), aff'd, Judgment of June 20, 1991, Cour d'Appel de Paris (Fr.) (on file with author).

120. French practice under the Convention is discussed in Alain Cornec, The Hague Convention on Abduction and Beyond, FAM. L., Mar. 1993, at 143-51.

121. [1991] 2 Fam. L. Rep. 241 (Eng. C.A. Dec. 21, 1990). 
custody in Arizona and initiating proceedings in England under the Convention were held to negate any inference of acquiescence. ${ }^{122}$ A somewhat conflicting decision was reached in another English Court of Appeal case ${ }^{123}$ involving a wrongful removal from Australia to England. In a split decision, the appeals court reversed the lower court's finding of no acquiescence. The evidence established that the father had written to the mother that her taking of the children was illegal but he was "not going to fight it."124 Unlike the trial court, the appellate court found that this act was sufficient for an acquiescence defense. One justice explained: "[i]t is not open to a parent who in clear terms says to the other that he accepts what has been done to come to the court and say that it was all a sham to deceive the other parent."125 One justice dissented, stating that acquiescence should not be viewed as a discrete event but rather interpreted in light of the primary goal of returning children wrongfully removed. Moreover, because the father was unaware of the summary remedy available to him under the Convention, the expression of his desire "not to fight" was not made knowingly. In a third English case, $\operatorname{Re} A Z,{ }^{126}$ the English Court of Appeal reversed a trial court's finding that the father had not acquiesced to the wrongful retention of his child by the mother's family. The mother had taken the child from Germany for a visit to England with the father's consent. After the mother's unilateral decision not to return to Germany, the child was left with the mother's aunt in England, who accepted the father's request that she temporarily care for the child. Subsequent to the aunt's commencement of English proceedings to prevent the father from returning with the child to Germany, the father initiated California divorce proceedings, in which the mother agreed that he should have the primary care and control of the child. On the father's Hague petition, the English trial court held that the father had not acquiesced to the aunt's retention of the child, reasoning that his intent was only to leave the child in the care of the aunt until he could take over care and control. In reversing, the Court of Appeal stated that acquiescence refers to "conduct inconsistent with the summary return of the child to the place of habitual residence." The court reasoned that the father's leaving the child with the aunt for the "time being" and the initiation of proceedings in California, rather than his seeking the child's summary return to Germany for the adjudication of custody in German courts, constituted acquiescence.

Although the "acquiescence" defense has been used only occasionally, the second exception-the Article 13b defense that return will expose the child to grave risk of physical or psychological harm or otherwise place the child in an

122. Id.

123. Re A and Another, [1992] 1 All E.R. 929 (Eng. C.A. Feb. 12, 1992).

124. Id.

125. Id.

126. [1993] 1 Fam. L. Rep. 682 (Eng. C.A. July 29, 1992). 
intolerable situation-has given rise to numerous cases. ${ }^{127}$ Indeed, this provision led to much debate in the drafting of the Convention because it was seen as a possible escape route for the Convention's overall goal-that custody decisions should be made by the state of habitual residence. As noted earlier, in the United States at least, ICARA implements a heavy "clear and convincing" burden of proof on the part of a defendant to establish this defense, and other countries have similarly construed the exception narrowly. A recent case in the United States, consistent with decisions in other countries, illustrates the limits of the $13 \mathrm{~b}$ defense. In Renovales $v$. Roos $a,{ }^{128}$ the family had been living in Spain. The mother came to Connecticut with the children to visit her family and, while there, filed for divorce and temporary custody of the children. When the husband petitioned in Connecticut for return of the children to Spain, the mother asserted the $13 \mathrm{~b}$ defense of severe harm to the children. The mother introduced expert testimony that the son suffered from a post-traumatic stress disorder attributable in part to behavior of the father. The father's expert opined that there were other reasons for the stress, including the mother's illness and the pervasive marital discord. In rejecting the $13 \mathrm{~b}$ defense, the court found that the criticisms of the father were attributable to "cultural differences in family child rearing that became more pronounced as love disappeared from the spousal relationship." 129 The court did not focus on whether or not it was possible for the mother to return to Spain with the children or whether her health might prohibit her return with them. The court observed:

The mother's desire to live away from her husband in the United States forms the basis of this tragedy. . . . She chose to love, marry, have children and live in Spain. The consequences of those choices must be faced. To allow any person to just rip their children out of their country of residence, for whatever reason, cannot be condoned by a court. ${ }^{130}$

In a similar case, Navarro v. Bullock, ${ }^{131}$ the parties had been living in Spain where they were divorced. Following a variety of custodial arrangements, a Spanish decree granted joint custody to the parties with the mother given physical custody and permission to bring the children to California for a visit for one month every other summer. The mother came to California with the children and then proceeded to retain and conceal them from the father for close to one year. The mother raised the $13 \mathrm{~b}$ grave harm defense in response to the father's petition for return. The court-appointed expert testified that removal from custody of the mother and return to Spain would be damaging, but the court nonetheless ordered return:

127. For a discussion of some of the early English-language cases under Article 13b, see Caroline LeGette, Note, International Child Abduction and the Hague Convention: Emerging Practice and Interpretation of the Discretionary Exception, 25 TEX. INT'L L.J. 287, 298-304 (1990).

128. No. 91-0392232-S, 1991 Conn. Super. LEXIS 2215 (Conn. Super. Ct. Sept. 27, 1991).

129. Id.

130. Id.

131. 15 Fam. L. Rep. (BNA) 1576 (Cal. Super. Ct. 1989). 
To retain the children in the United States guarantees that the mother will continue to frustrate the custodial and visitation rights. of the father, and to undermine his relationship with his children... To allow this to happen would be to allow the mother to profit by her own wrong, and to continue to damage the children psychologically by her unwillingness to allow the father access to his children. Thus, the mother has failed to convince this court by clear and convincing evidence that there is a grave risk that the children will be exposed to psychological harm by their return to Spain. ${ }^{132}$

A later phase of the Tahan v. Duquette ${ }^{133}$ custody litigation, discussed earlier, gave a New Jersey appellate court the opportunity to provide some helpful parameters in delineating the "grave harm" exception. In an earlier phase of the proceeding, the court had determined that Canada was the habitual residence of the child but remanded the case for the limited purpose of determining whether return would expose the child to a grave risk of physical or psychological harm or create an intolerable situation under Article 13b of the Convention. At the hearing, the father, who resisted return, attempted to offer the testimony of four witnesses, including a court-appointed clinical psychologist who had interviewed the families and prepared an evaluation and a teacher who would testify about "how the child would be affected by the decision" to return the child to Canada. ${ }^{134}$ The trial court rejected the proffered testimony, holding that the focus of the Article $13 \mathrm{~b}$ inquiry should be limited to the question of whether there exists in the place of habitual residence such "internal strife or unrest as to place the child at risk." 135 The appellate court rejected that reading as "too narrow and mechanical," but it did agree with the lower court that psychological profiles and detailed evaluation of parental fitness and lifestyles were inappropriate avenues of inquiry on a return petition. ${ }^{136}$ Rather, it asserted that a court should focus on whether a realistic basis exists for apprehensions concerning the child's well-being by evaluating the "surroundings to which the child is to be sent and the basic personal qualities of those located there."137 Because there had been no intention to address those issues in the proof, the lower court's decision to return was affirmed. ${ }^{138}$

By and large, courts in other countries have also refused to allow the $13 \mathrm{~b}$ exception to become a substitute for "best interests" and appropriately have not converted the jurisdictional focus of the Convention into one of merits. ${ }^{139}$ For

132. Id. at 1577; see also In re Prevot, No. Misc. 93-61-M1, 1994 U.S. Dist. LEXIS 8190 (W.D. Tenn. 1994) (testimony of clinical psychologist who examined children but could not state with certainty the source of stress was not sufficient to establish defense by clear and convincing evidence).

133. 613 A.2d 486 (N.J. Super. Ct. App. Div. 1992).

134. Id. at 488.

135. Id. at 489 .

136. Id.

137. Id.

138. The Tahan/Duquette litigation is discussed in Ira Lurvey, Not Just Law But Wisdom, 15 FAM. ADVOCATE, Spring 1993, at 8.

139. See, e.g., $\operatorname{Re} H$ (Eng. C.A. Aug. 20, 1991) (Lexis, Enggen library, Cases file) (transcript) (reversing trial court's order of no return; court erred in applying Article 13 b by looking to the long-term effects of a return order rather than considering only immediate risk from return). 
a short time, there were several unfavorable decisions by the lower Swiss courts, including von Glasow v. von Glasow, ${ }^{140}$ where a father living in Michigan failed to secure return of his children who were taken by their mother to Switzerland. The Swiss court refused to order the children returned because the mother refused to return to the United States, and the social services report had determined that the children were closer to their mother and returning them would thus result in psychological harm to them. The decision was later reversed on appeal and the children were ordered returned. ${ }^{141}$ A more recent decision by another Swiss court, Korowin v. Korowin, ${ }^{142}$ did result in the initial return of a young two-year-old child to its habitual residence in Michigan, despite the argument that there would be serious psychological harm in removing this young child from his only caregiver, as the mother did not wish to return to the United States. In rejecting the Article $13 \mathrm{~b}$ defense, the court discounted the mother's reasons for not returning - better opportunities in Switzerland for a job and in the divorce proceedings-holding that a defendant must be absolutely unable to return with the child. The court noted that there was little hardship to the wife, who was not being forced to return to the husband or to live in his household; it also emphasized the husband's willingness to provide housing and bear costs while custody proceedings were pending in Michigan. The Swiss court found one drawback in the Convention-that only the return of the child is required; the court thought the Convention should also require return of the parent. In the Korowin case, the court was concerned that harm would come to the child if the mother refused to return with the child, but it was confident that "a responsible mother who has the interest of her child at heart" would not refuse to accompany the child on its return. And should she refuse, it would be assumed that the mother was placing her own welfare above that of the child. Thus, held the court, it was "exclusively up to the defendant whether [the child] will be exposed to a serious risk of physical or psychological harm within the meaning of [Article 13] .... This is not sufficient under the existing jurisprudence and case law to deny the return of the child ...."143

140. Judgment of Sept. 15, 1989 (von Glasow v. von Glasow), 15 Fam. L. Rep. (BNA) 1605-06, Bezirksgericht Uster-No. 5689096 U/ER2SV (Switz.).

141. Judgment of Dec. 14, 1989 (von Glasow v. von Glasow), Obergericht (Ct. App.) des Kanton Zurich (Switz.), noted in Hague Conference on Private International Law, Preliminary Doc. No. 5 for attention of Special Commission of Jan. 1993 (on file with author) (listing country-by-country court decisions on Hague Convention); see also Judgment of Dec. 5, 1991 (Barlow v. Barlow), Obergericht (Ct. App.) des Kanton Solothurn (Switz.) (available on Hilton BBS) (lower court order of no return on the basis of harm to a young child reversed on appeal).

142. Judgment of Feb. 13, 1992 (Korowin v. Korowin), No. 138036, Bezirksgericht (Dist. Ct.) des Kanton Horgen (Switz.) (available on Hilton BBS).

143. One factor that can dissuade an "abducting" parent from returning with the child is an outstanding warrant for arrest of that parent in the requesting state. See, e.g., Judgment of Oct. 28,1992 (Foxman v. Foxman), M.A. 2898/92, Dist. Ct. Tel Aviv (Isr.) (on file with author) (mother testified that there was a warrant for her arrest in Canada). Of course, in many situations, prosecutors will not pursue criminal proceedings if the child is ultimately returned. See SECOND SPECIAL COMMISSION REPORT, supra note 7 , at 64 . 
A recent French case, In re Shamee, ${ }^{144}$ provided an unfortunate interpretation of the Article 13b "grave risk" defense. In ordering the immediate return of children wrongfully removed by the mother from the United States to France, the first instance court rejected the mother's $13 \mathrm{~b}$ defense. The appellate court reversed, however, and stated that the "grave risk" to the children was not that of being returned to the United States and to the father, but that of being separated from the mother, which the court stated would be the "equivalent of bereavement." 145

Other courts have offered different solutions to deal with the problem of separating young children from their primary caretaker when that parent refuses to return to the habitual residence. In $C v . C{ }^{146}$ the mother wrongfully took her child from Australia to England. She then claimed the child would be psychologically harmed if the child had to return alone to Australia. The mother stated that she could not return to Australia because she had no money or employment. The court stated that a parent could not rely on the psychological harm that might result from her own refusal to return with the child, but it conditioned its order on the promise of the father to provide financially for the mother and child in Australia. Similarly, in $\operatorname{Re} H^{147}$ the mother brought the children to England in violation of a custody agreement approved by the Arizona courts. The lower court had refused to order return of the children because the mother and children were settled in England, and forcing them to return to Arizona would be disruptive and create severe unhappiness. ${ }^{148}$ The Court of Appeal allowed the appeal and ordered return, keeping the children in the custody of their mother "until their future is properly determined in the courts of Arizona." 149 Nonetheless, the English court-accustomed to the exercise of discretion in family matters-commented on the hardship often worked by the treaty:

The circumstances command the sympathy of the court, but the court's hands are tied by the treaty itself. There is no option or discretion. I suppose it is fair to say that the treaty only comes into effect after the wrongful conduct of the mother herself. But nevertheless I would not like to part with this judgment

144. Judgment of Mar. 12, 1993 (In re Shamee), Trib. gr. inst. de Colmar 2d (Fr.) (available on Hilton BBS).

145. Id. Several first level courts in Germany have also denied return where mental health experts testified that return would have a serious negative impact on the child's development. See, e.g., Judgment of Mar. 19, 1992, AZ 1 F 124/91, Amtsgericht Pirmasens; Judgment of May 5, 1992, AZ 12 F 304/91 HK, Amtsgericht Vechta. However, the German appellate courts seem less receptive to nonspecific allegations of harm. See, e.g., Judgment of May 18, 1992, AZ 17 UF 92/92, Oberlandesgericht Celle, reversing Judgment of Mar. 30, 1992, AZ 23 F 73/92, Amtsgericht Celle, and Judgment of July 6, 1992, AZ 11 UF 520/92, Oberlandesgericht Koblenz. German decisions on the Hague Abduction Convention are summarized by Dagmar Schreiber in Hague Conference on Private International Law, Preliminary Doc. No. 2 for attention of Special Commission of Jan. 1993 (on file with author).

146. [1989] 2 All E.R. 465 (Eng. C.A. Dec. 14, 1988).

147. (Eng. C.A. Aug. 20, 1991) (LeXIS, Enggen library, Cases file) (transcript).

148. Id.

149. Id. 
without saying that the court is very mindful of the stress, tensions, and anxiety that proceedings under this particular treaty inevitably cause. ${ }^{150}$

An analogous issue was presented to the Supreme Court of Canada in the first case on the Hague Convention to come before that court, Thomson. $v$. Thomson. ${ }^{151}$ The Manitoba Court of Appeal had ordered return of a child who was taken by the mother from Scotland to Canada in violation of an interim custody order preventing removal. A dissenting judge on the Court of Appeal argued, however, that the return order should be stayed, that continuing interim custody should be given to the mother, and that she should initiate a new custody application in Scotland. ${ }^{152}$ The concern expressed was that the environment of a young child should not be repeatedly changed, and that in this case it was likely that the mother would ultimately obtain permanent custody. The Canadian Supreme Court dismissed the appeal, thus ordering immediate return, on the basis of an undertaking by the father not to exercise his right to custody upon return. ${ }^{153}$ However, the Court avoided the interesting issue presented by the unique Manitoba law that permits a court, even when it has found that a child has been wrongfully removed or retained, to make an interim custody order and stay the application for the child's return subject to conditions it deems appropriate-a provision seemingly in conflict with the requirements of the Hague Convention. ${ }^{154}$

The "abducting" parent has something of a quandary in deciding whether to agree to accompany the child if return is ordered. In an English case, $\operatorname{Re} A,{ }^{155}$ a psychiatrist testified that the child's development would be "imperilled" unless he was placed in the mother's custody. At the hearing, the mother acknowledged that she would return to Canada with the child if return were ordered, and the judge then relied upon that fact to show there was no grave risk of psychological harm. On appeal, the mother explained that she had not considered the arrangements that would be required to return to Canada and that she had been thinking only of her child's welfare. However, she insisted that she could not now comply with the order to return. The English Court of Appeal dismissed the mother's appeal, stating that the trial court had assessed her credibility on the issue of her return and that the risk of harm was not sufficient to fall within Article 13b. In some situations of hardship or returns, courts have requested additional undertakings by the applicant. For example, in $C v$. $C$, discussed earlier, the petitioning father agreed to pay for support and

150. Id.

151. 50 R.F.L.(3d) 145 (Manitoba C.A. 1993).

152. On an ex parte application of the father after removal, the Scottish courts awarded custody to the father.

153. On January 26, 1994, the Supreme Court of Canada dismissed the appeal in an oral judgment, stating that reasons would follow in a subsequent opinion.

154. See Vaughan Black, Annotation, 50 R.F.L.(3d) at 147-50, noting that the Manitoba legislation has the potential to "put Canada in breach of its international obligation to implement fully and without limitation the terms of the Convention."

155. [1988] 1 Fam. L. Rep. 365 (Eng. C.A. June 10, 1987). 
accommodations for the child and accompanying mother. The Irish Supreme Court, in $P F v . M F{ }^{156}$ imposed an even greater burden on the parent resisting the "risk of harm" defense. A lower court had ruled that children should be returned to the United States even though the father's past behavior in failing to pay rent had placed the family in "intolerable" circumstances. Apparently, the lower court judge believed that the father's willingness to abide by an order imposing certain conditions of payment justified an order of return. However, the Supreme Court reversed, stating that return should be ordered only if the father had actually proved that he had already made the necessary arrangements for the care of his family, including provision of a residence and money for the mother and children's upkeep.

Another construction of Article $13 \mathrm{~b}$ was offered by an Australian court to keep the exception a narrow one. In Gsponer v. Johnstone, ${ }^{157}$ the Australian court emphasized that the Convention's concern was whether the child's return to the other country-here Switzerland-posed a grave risk of harm:

[Article 13b] is confined to the "grave risk" of harm to the child arising from his or her return to a country which Australia has entered into this Convention with. There is no reason why this court should not assume that once the child is so returned, the courts in that country are not appropriately equipped to make suitable arrangements for the child's welfare. Indeed the entry by Australia into the Convention with the other countries may justify the assumption that the Australian Government is satisfied to that effect. Thus allegations about inappropriate conduct on the part of the parent in the requesting state are irrelevant. ${ }^{158}$

This interpretation, though helpful in limiting the scope of $13 \mathrm{~b}$, does not appear to be consistent with $13 \mathrm{~b}$ 's focus on "conduct of the parties" or "the interests of the child." 159 Moreover, such interpretation appears redundant in

156. 1992 No. 390 (Ir. Sup. Ct. Jan. 13, 1993) (transcript) (LEXIS, Irelnd library, Cases file).

157. 12 Fam. L. Rep. 755, 766 (Austl. Fam. Ct., Melbourne, Dec. 23, 1988) (available on Hilton BBS).

158. Id. at 768 (emphasis added). In a recent custody litigation involving children wrongfully removed from a non-Convention country (South Africa) to the United States, the abducting mother argued that the Article 13b Hague Convention defenses of "grave risk of harm" and "intolerable situation" were available to her in a custody litigation in which the husband sought custody and return of the children as a matter of state law. The mother's position was that although a parent from a noncontracting state could not make affirmative use of the Convention, the Article 13b defenses were nonetheless applicable because they had either been incorporated into state custody law or trumped inconsistent state law under the Supremacy Clause. The argument has some appeal in the sense that otherwise a pursuing parent from a nonsignatory state might be seen to have a better chance of achieving return than a parent from a Convention state. The substance of the $13 \mathrm{~b}$ defense was that conditions in South Africa - terrorism, violence, war, and crime-created a grave risk of harm as well as an intolerable situation. A settlement on custody was reached by the parties before the court ruled on the availability or the merits of the defense. The litigation, Golden v. Golden, is discussed by Professor Robert J. Levy, who acted as counsel for the wife, in Robert J. Levy, The Hague Convention "In the Trenches": International Custody Law in American Courts, delivered at the International Society of Family Law Triennial Conference: Families Across Frontiers, Cardiff, Wales, United Kingdom, July 1, 1994 (manuscript on file with author).

159. PÉREZ-VERA REPORT, supra note 2, at 434. A similar observation was made by the New Jersey appellate court in Tahan v. Duquette, 613 A.2d 486, 489 (N.J. Super. Ct. App. Div. 1992), discussed 
light of the Article 20 exception, which excepts return when inconsistent with fundamental principles of the requested state relating to protection of human rights and fundamental freedoms. Thus, Article 20 -but not $13 \mathrm{~b}$-is directed to concerns about harms arising from the child's return to a particular country. As of yet, there have been no refusals to return based on Article $20 .{ }^{160}$ Article 20 was introduced as a compromise measure to resolve the debate concerning the role of "public policy" concerns of a requested state. A suggested reservation was proposed that would have permitted contracting states to avoid return when the return would be "manifestly incompatible with the fundamental principles of the law relating to the family and children in the State addressed."161 Such a "public policy" exception might well have undermined the central premise of the Convention-that the child's habitual residence should decide the issues of custody - by permitting a requested state to prophesy and evaluate an outcome in the state of habitual residence or to condone under certain circumstances the conduct of the abductor. With the substitution of Article 20, the role of the state of refuge is much more limited: only matters of "human rights and fundamental freedoms" qualify-most likely defined within the parameters of other international agreements-and those principles must prohibit the return. ${ }^{162}$

supra at text accompanying notes 133-38.

160. One French court of first instance did rule that an English father who had taken his children to France without the mother's consent (which was required by court order) was not subject to a return order. The court held that recognition of Convention rights would violate the rights to free movement and to choose one's residence guaranteed by the European Convention on Human Rights. Bruch, International Child Abduction Cases, supra note 23, at 353, 360. The French appellate court reversed, however, finding that the father's freedom to move was not restricted. Id. The case is Judgment of Mar. 23, 1989 (Ministère Public v. M. B), Cour d'Appel d'Aix-en-Provence (Fr.) (on file with author).

Several other courts have addressed related "human rights" issues in ordering return. For example, in Parsons v. Styger, 67 O.R.2d 1 (Sup. Ct. Ont. 1989), appeal dismissed, 67 O.R.2d 11 (Ont. C.A. 1989), an Ontario court rejected the abducting mother's claim that an order for return violated the Canadian Charter of Rights and Freedoms, which guarantees citizens of Canada the right to enter and remain in Canada. The court held that the child, even though a Canadian citizen, does not have the right to remain in Canada in contravention of the Hague Convention. In an Australian case, Murray v. Director, Family Services, Appeal No. EA 51, File No. CA 1162 (Austl. Full Fam. Ct., Sydney, Oct. 6, 1993) (on file with author), discussed infra at text accompanying notes 267-68, the court rejected the argument that the Hague Convention was inconsistent with the U.N. Convention on the Rights of the Child, and in any event observed that the Hague Convention, having been incorporated into Australian domestic law, would trump in any conflict with the U.N. Convention. Finally, in an unappealed decision of a French tribunal, Judgment of Mar. 17, 1992 (Ministère Public v. Mme Y), Trib. gr. inst. de Périgueux, D.S. Jur., June 18, 1992 (Fr.), the court stated that an order restricting the custodial mother from removing the children from England or Wales without the father's consent was an impermissible restriction on her mobility and violated Article 2 of the Fourth Additional Protocol to the European Convention on Human Rights and Fundamental Freedoms. Although there were alternate grounds for the court's refusal to order return, the human rights issue was noted by French commentators. The case is discussed in Hague Conference on Private International Law, Preliminary Doc. No. 1 for attention of Special Commission of Jan. 1993 (setting forth checklist of issues) (on file with author).

161. PÉREZ-VERA REPORT, supra note 2, at 433-34.

162. A recent student note offers a misguided view on how Article 20 should be interpreted. See Dorothy Carol Daigle, Note, Due Process Rights of Parents and Children in International Child Abductions: An Examination of the Hague Convention and its Exceptions, 26 VAND. J. TRANSNAT'L L. 865 (1993). The note suggests that Article 20 can be invoked whenever the state of habitual residence does not ensure a U.S. party a "due process" hearing on the issue of custody and urges that on a return petition in the United States, parties be permitted to show that courts in other countries will not provide 
Another questionable return refusal on the basis of an "intolerable situation" occurred in d'Assignies v. Escalante. ${ }^{163}$ There, a California court refused to return a child from California to France when the children had already been the subject of a prior abduction by the parent petitioning for return. ${ }^{164}$ The situation involved unmarried parents living in California when the children were born. The mother obtained an order in California granting her custody of the children. The parties later moved to France, and the children lived most of the time at the father's home. The father, thinking that the mother was about to leave France with the children, abducted the children and hid them from the mother. During that period, he brought proceedings in France to establish his own parental authority with respect to the children. ${ }^{165}$ Before any decision was reached, the French court arranged a stipulation, whereby the mother obtained temporary custody of the children in France and was ordered not to leave. Nonetheless, the mother-who had told the judge that the children's U.S. passports were lost-left France with the children and came to California, where the father invoked the Hague Convention. During the California proceedings, the father, who had been granted visitation with the children, abducted them to France. The California court then ruled on the father's petition, holding that France was the habitual residence of the children and that the father-by virtue of the limitation on the mother's removal of the children-had "rights of custody." Nonetheless, the court refused to order the return of the children to France because of the "intolerable situation" to which they had been exposed.

a "due process" hearing. Id. at 879-87. To the extent the argument is a general one-that Convention states should offer a fair procedure for the ultimate resolution of the custody dispute-it is sufficient to point out that Hague Conference signatories (member states in 1980) who ratified the Convention do meet that standard. With respect to acceding states, the United States need not accept the accession of any state if there are doubts about the overall fairness of its judicial processes. To the extent, however, that the student note argues that the specifics of U.S. procedure for custody adjudication must be duplicated in a foreign state in order for return to be ordered, the conclusion is flawed and myopic. Such a view evidences a parochialism that is inconsistent with U.S. obligations in a multi-national community and as a party to international treaties. To take one analogy, the United States does not enforce foreign country judgments that do not provide impartial tribunals or generally fair procedures. See RESTATEMENT (THIRD) OF THE FOREIGN RELATIONS LAW OF THE UNITED STATES $\$ \$ 481-488$ (1987). However, differences in the methods or standards of proceeding, such as admission of evidence, unavailability of cross-examination, or standards for the exercise of jurisdiction or the awarding of custody do not justify a refusal to enforce. See Andreas F. Lowenfeld \& Linda J. Silberman, On the Enforcement of Judgments in the United States of America, in ENFORCEMENT OF FOREIGN JUDGMENTS WORLDWIDE 123-36 (Charles Platto \& Willam G. Horton eds., 2d ed. 1993). In the case of the return obligation under the Convention, the argument for return is even stronger because the premise of the Convention-agreed to by all parties to it-is that the state with the greatest interest in applying its procedures and its standards is the state of "habitual residence."

Before one gives any credence to the views of the student author, it should be pointed out that the note also contains several errors, such as just who the parties are to the Hague Abduction Convention. South Africa, for example, is not a party to the Convention as of 1993 , notwithstanding the author's statement and citation that it is. Perhaps the author is referring to the fact that South Africa is a signatory to a different Convention, the U.N. Convention on the Rights of the Child, Nov. 20, 1989, 28 I.L.M. 1448 (1989), which was signed by South Africa on January 29, 1993.

163. No. BD 051876 (Cal. Super. Ct., L.A. Cty., Dec. 9, 1991) (available on Hilton BBS).

164. Id.

165. See Judgment of July 22, 1992 (Escalante v. d'Assignies), Nos. 91-5498 \& 91-6093, Cour d'Appel de Covessone (Fr.) (available on Hilton BBS). 
Noting that the children were victims of "two wrongful kidnappings by the father," the court found that there was a grave risk that continued custody by the father in France would expose them to psychological harm. Interestingly, the California court also requested the Central Authorities in both France and the United States to bring about the immediate and prompt return of the children to California. This case seems to be one where both parties had "unclean hands," but the California court's invocation of the "intolerable situation" defense is not the solution. Since the children remain in France, a Convention proceeding in France is necessary to secure return, and since the mother's conduct before the French courts was equally contumacious-misrepresenting that the passports were lost and violating the French court's prohibition on taking the children from France-a French court might have similar misgivings about ordering return to California.

The "at fault" issues are difficult to sort out on "return" questions, and for the most part the Convention tries to avoid such inquiries. Once having determined that the habitual residence was France, the California court should have entrusted jurisdiction to the French courts to untangle the whole custody story and to make the appropriate determination. Indeed, if need be, some temporary alternative arrangement for custody, such as using third parties or other social services, might have been arranged in France. Of course, at the time the California court made its decision, the father was still in hiding with no assurance that he would resurface, whatever the decision of the California court. However, evaluations about the conduct of the parties are not likely to achieve the objectives of the Convention, and attempts to do so are likely to occasion competing value judgments by other courts. If the Convention is to work, courts will need to defer-regardless of the parties' conduct and unless there is no satisfactory alternative custody arrangement in the state of habitual residence-to the courts of habitual residence.

The Convention also spells out several other situations that may justify a requested state's refusal to return a child when a request for return has been filed. First, it should be noted that the Convention ceases to apply at any point when a child reaches the age of sixteen years; thus a child who reaches the age of sixteen at any stage of the proceedings is no longer subject to return, ${ }^{166}$ even though the wrongful abduction or the start of proceedings occurred when the child was under sixteen. Second, pursuant to Article 13, the judicial or administrative authority may refuse "to order the return of the child if it finds that the child objects to being returned and has attained an age and degree of maturity at which it is appropriate to take account of its views."167 Finally, when a period of one year or more has elapsed between the date of the "commencement of the proceedings before the judicial or administrative authority of the contracting state where the child is" and the date of the

166. Hague Convention, supra note 1, art. 4, S. Treaty Doc. No. 11 at 7, 19 I.L.M. at 1501.

167. Id. art. 13, S. TREATY DOC. NO. 11 at 10, 19 I.L.M. at 1502. 
wrongful removal or retention, the child need not be returned if it is "demonstrated that the child is now settled in its new environment." 168

The age limit has not produced particular difficulties in interpretation since the Convention and report are quite clear that the applicability of the Convention is terminated at any stage of the case when the child reaches sixteen. ${ }^{169}$ Indeed, the United States had objected to this provision and proposed that the Convention cover any child who was under sixteen at the time of the breach of custody or access rights; ${ }^{170}$ the United States feared that abductors could take advantage by using various delaying tactics both before and during judicial or administrative proceedings. ${ }^{171}$ However, the more restrictive option was retained in the Convention. ${ }^{172}$

Closely related to the age limit for application of the Convention is the question of a child's right to choose its own residence. ${ }^{173}$ Although the Convention will still apply in such a case, under the second paragraph in Article 13 , the judicial or administrative authority may refuse to order return if it finds that the child objects to being returned and has attained an age and degree of maturity at which it is appropriate to take account of its views. ${ }^{174}$ In one recent case, Bickerton v. Bickerton, ${ }^{175}$ the parties had a separation agreement proyiding for alternating physical custody between the father in Canada and the mother in California. When the mother refused to return the children to Canada, the father brought a Hague petition in California. The twelve-year-old daughter objected to the return, but the court found that there was insufficient evidence that either the ten-year-old boy or the twelve-year-old girl were of sufficient age and maturity for the court to take account of their views. ${ }^{176}$ Courts in other countries have also been reluctant to avoid return by reliance on this provision. In an interesting Swiss case, Rajaratnam v. Rajaratnam-Hertig, a lower court refused to order return to the United Kingdom of two children, ages fourteen and twelve, who objected to being returned. The Higher Court of the Canton of Zurich reversed the decision, and its decision to order return was upheld by the Supreme Court of Appeals (Cour de Cassation) of the Canton of

168. Id. art. 12, S. TREATY DoC. No. 11 at 9, 19 I.L.M. at 1502 .

169. See Comments of the Governments on Preliminary Document No. 6 (Prelim. Doc. No. 7), in ACTS AND DOCUMENTS, CHILD ABDUCTION, supra note 2, at 240.

170. Id.

171. Id.

172. See PÉREZ-VERA REPORT, supra note 2, at 450.

173. Under some laws, a child under sixteen may have the right to choose its own residence. Some thought was given to making the Convention inapplicable in such cases. See id. However, given the existence of Article 13's second paragraph-allowing the child's objection to return to be taken into account-the same result may be achieved without an overall reduction in the scope of the Convention. Id.

174. Hague Convention, supra note 1, art. 13, S. TREATY DoC. No. 11 at 10, 19 I.L.M. at 1502.

175. No. 91-06694 (Cal. Super. Ct., Contra Costa Cty., July 17, 1991) (available on Hilton BBS).

176. I have found one U.S. case in which a court, after interviewing the child, deferred to the child's wishes and refused return. See Matter of McIntyre \& Hammon (Kan. Civ. Ct., Johnson Cty., July 15, 1990) (on file with author). Unfortunately, the opinion contains neither the age of the child nor the reasons for the child's objection to returning to Australia. 
Zurich. ${ }^{177}$ The Supreme Court noted that it was appropriate to examine the emotional situation of the children and the reasons for their objection in evaluating how much weight to accord to the children's wishes. Here, where the children had not seen their father for several months and had been exclusively in contact with the mother and her relatives and where the children were concerned about their mother's illness, the court was correct in disregarding the wishes of the children in favor of objective facts. In a Swedish case, Shamsi $v$. Heijkenskjold-Shamsie, ${ }^{178}$ an appellate court honored the wishes of a fourteenyear-old girl to remain with her mother in Sweden but at the same time ordered the return of a younger brother, age nine, to England. A lower court had refused return of both children based on their expressed preferences, but the appeals court would give weight only to the wishes of the older sibling. ${ }^{179}$

Courts interpreting this defense generally require evidence that demonstrates more than a child's preference to remain with the abducting parent. ${ }^{180}$ In $S v$. $S,{ }^{181}$ the English Court of Appeal affirmed a trial court's refusal to order return based on the child's objections. The English mother had abducted the child from France to England. On the French father's Hague petition, the trial court found that the nine-year-old child objected to return and was of sufficient age and maturity for the court to consider her views. The Court of Appeal agreed and stated that discretion to refuse return should be reserved for exceptional cases. Here it found the lower court's order was proper, because the child's objections to living in France had substance and were not based merely on a preference to remain with the mother in England. Other courts have been more restrained in applying this defense, reflecting a desire not to have a court in the jurisdiction to which a child was removed consider the merits of a case. ${ }^{182}$

The time limits and discretion addressed in Article 12, ordering return after one year unless the child is settled in its new environment, are the product of an

177. Judgment of Dec. 19, 1988 (Rajaratnam v. Rajaratnam-Hertig), Kassationsgericht (Sup. Ct. App.) des Kanton Zurich (Switz.) (available on Hilton BBS).

178. Judgment of June 19, 1990 (Shamsi v. Heijkenskjold-Shamsie), No. 1731-1990, Sundsvall Admin. Ct. App. (Swed.) (on file with author).

179. The appeals court relied on parallel provisions of the Swedish Code on Parents and Children, which provides that enforcement of a custody decision should ordinarily not take place against the wishes of a child if the child has attained the age of 12 .

180. See, e.g., Re R, [1992] 1 Fam. L. Rep. 105 (Eng. Fam. Apr. 24, 1991) ("[T]here must be more than a mere preference expressed by the child. The word 'objects' imports a strength of feeling which goes far beyond the usual ascertainment of the wishes of the child in a custody dispute."); Re RPW, 1992 No. 106SP (Ir. High Ct. Feb. 19, 1992) (transcript) (LEXIS, Irelnd library, Cases file) (mother failed to prove child's objections to return where child had a strong preference for his mother but did not fear his father); Judgment of Oct. 28, 1992 (Foxman v. Foxman), M.A. 2898/92, Dist. Ct. Tel Aviv (Isr.) (on file with author) (desires of children, 11, 10, and 7, to remain in Israel rather than return to Canada were influenced by mother and were not "authentic, mature, or worthy of consideration").

181. [1992] 2 Fam. L. Rep. 492 (Eng. C.A. July 2, 1992).

182. See, e.g., P v. P, [1992] 1 Fam. L. Rep. 155 (Eng. Fam. Aug. 7, 1991) (court has no duty to make a detailed investigation into child's views as the Convention is peremptory in nature and assumes that courts of the signatory states are "equally capable of ensuring a fair hearing"); $\operatorname{Re} G,[1989] 2$ Fam. L. Rep. 475 (Eng. C.A. Apr. 27, 1989) (court in jurisdiction of child's habitual residence is the appropriate forum for investigation of the child's "true wishes"). 
important compromise in the treaty process. Earlier drafts of the treaty authorized return only if proceedings were brought within specific time limits, varying on whether or not the child was concealed. ${ }^{183}$ Here again, the United States expressed concern that these restrictive time limits would make the treaty impractical in the United States where, in the absence of any identity registration system, location of abducting parents and abducted children is difficult and timeconsuming. ${ }^{184}$ In addition, parties might be encouraged to arrange for life underground for a limited period in order to circumvent the Convention. ${ }^{185}$ Under the final treaty version, the fact of the child's integration into a new environment is balanced with the overall return objective of the treaty by continuing to order return "unless it is demonstrated that the child is now settled in its new environment." 186 As with other defenses, a court retains discretion whether or not to return. A recent Ohio appeals court ordered return of a fiveyear old child, who had been taken by his father to Ohio from the habitual residence in Australia in 1991, despite the fact that a petition for return was not filed until three years after the wrongful removal. ${ }^{187}$ The court was influenced by the relatively short (ten-month) period that the child had actually been in Ohio and by the failure of the father to present evidence that the child had been enrolled in school or had close ties in the community. However, in another case, the court did refuse to order return of a very young (twenty-month-old) child to England because the child had been in Colorado from the time she was twomonths old. ${ }^{188}$ In cases of wrongful retention, a question may arise as to the proper time from which to measure the one-year period. In one interesting case, ${ }^{189}$ the court, in dicta, held that when a child, pursuant to the parents' agreement, resides with the parent from whom custody is later sought, the wrongful retention does not begin until the noncustodial parent clearly communicates the desire to regain custody.

\section{F. Special Problem of Access Rights}

A removal which violates visitation or access rights does not trigger the mandatory return of an abducted child. While Article 21 of the Convention provides that access applications may be made in the same manner as return

183. Preliminary Draft Convention adopted by the Special Commission and Report by Elisa PérezVera (Prelim. Doc. No. 6 of May 1980), in ACTS AND DoCumENTS, CHILd ABduction, supra note 2, at 168 .

184. Id. at 242.

185. Id.

186. Hague Convention, supra note 1, art. 12, S. TREATY DoC. No. 11 at 9, 19 I.L.M. at 1502.

187. In re Coffield, No. 94-P-0034, 1994 Ohio App. LeXIS 2546 (Ohio Ct. App. June 3, 1994).

188. In re Marriage of Collopy, No. 90 DR 1138 (Col. Dist Ct., Div. B, Adams Cty., May 8, 1991) (available on Hilton BBS), discussed in text accompanying note 89.

189. Slagenweit v. Slagenweit, 841 F. Supp. 264 (N.D. Ia. 1993). Nonetheless, the court in this case did not order return because it found that the child's habitual residence had changed from Germany to Iowa as the result of the child's integration into the community while residing in Iowa for an indefinite period pursuant to the mutual agreement of the parents. The case is discussed in text accompanying notes $108-10$. 
applications, the Convention does not provide for mandatory return. The only affirmative obligations imposed on a Central Authority are to adhere to the Article 7 obligations of cooperation and to remove any obstacles to an applicant's rights of access, to the extent this is possible. Though a court may return a child for visitation as a matter of discretion, ${ }^{190}$ more likely it will order that access be provided in the state to which the child has been removed. Further, a court may impose its own conditions on an applicant's access rights, even if there is a prior order of a court of the jurisdiction from which the child was removed.

Recent cases demonstrate the latitude afforded a court under Article 21. In the case of $\operatorname{Re} G$, the English Court of Appeal held that the Convention applied to access rights granted by a Canadian court, but that a breach of those access rights would be considered under the law of England. ${ }^{191}$ A Canadian custody order had permitted the mother to return to England with the child to live, but it required the mother to provide the father with access to the child in Canada. On the mother's refusal to return the child to Canada for visitation, the father commenced a Hague proceeding in England. Rejecting the father's argument for return of the child for access, the English court stated that Article 21 did not mandate enforcement of access rights, but rather provided for the exercise of such rights by seeking the assistance and intervention of Central Authorities in contracting states. The request must be made as a request for access rights directed to the courts of the child's habitual residence-here England-and the English courts were free to determine the proper locale for the exercise of these rights.

In another English case, $C$ v. $C{ }^{192}$ the court held that nothing in the Convention displaces the notion that the welfare of the child is the paramount principle in deciding questions of access. Subsequent to a New York court order granting custody of the children to the mother and visitation to the father, the mother removed the children to England. The father, initially seeking the return of the children to New York, at the hearing sought only a declaration that the children had been wrongfully removed and access to the children. The court held that the mother's removal of the children to England was wrongful under Articles 3 and 5 of the Convention, as New York case law implicitly prohibited a custodial parent's removal of the children to a distant locality such that the other parent's rights of visitation would be frustrated. This prohibition apparently gave the access parent rights of custody for purpose of ordering return. However, the court held that since the father did not seek the return of the children, the New York decree was no longer relevant and the English court had the jurisdiction to resolve issues of access based on the welfare of the child. Because of the poor nature of the father's relationship with the children, the

190. See, e.g., Viragh v. Foldes, 612 N.E.2d 241 (Mass. 1993), discussed supra at notes 58-60 and accompanying text.

191. [1993] 1 Fam. L. Rep. 669 (Eng. C.A. Dec. 9, 1992).

192. [1992] 1 Fam. L. Rep. 163 (Eng. Fam. Aug. 21, 1991). 
court limited the father's access to supervised visits which were to occur in England. These open-textured rules for securing access rights may prove unfortunate, as was noted by the Report of the Second Special Commission. ${ }^{193}$ Without a direct command for enforcement, Central Authorities may be unwilling to act, and even when they do, there may not be sufficient weight given to such rights. For example, in the $\operatorname{Re} G$ case, it is likely that the Canadian court conditioned the custodial parent's move to England on allowing access to be exercised in Canada. In the future, a court may be less likely to allow the removal, understanding that limitations in its orders may be unenforceable.

\section{RElationship of THE CONVENTION TO OTHER Custody LAWS IN THE UNITED STATES}

The Hague Convention is not the only civil remedy for dealing with international child abduction in the United States. Article 29 of the Convention provides that the Convention shall not preclude application directly to the judicial or administrative authorities of a contracting state, "whether or not under the provisions of the Convention."194 Accordingly, ICARA expressly provides that remedies under the Convention are not exclusive. ${ }^{195}$ In the United States, the Uniform Child Custody Jurisdiction Act ("UCCJA"), 196 enacted in some form in every state, ${ }^{197}$ includes standards for both the exercise of custody jurisdiction and the enforcement of custody decrees. Most states that have adopted the UCCJA have included Section 23, which extends the general policies of the Act to international cases. ${ }^{198}$ Thus, in some situations, a party may have a remedy under the UCCJA as well as under the Convention. ${ }^{199}$

193. See Second Special Commission Report, supra note 7, at 243-44; see also Adair Dyer, Summary of Remarks by Adair Dyer on the Application of the Hague Child Abduction Convention to Questions of Access (Visitation), in ABA SYMPOSIUM, supra note 9.

194. Hague Convention, supra note 1, art. 20, S. TrEATY Doc. No. 11 at 11, 19 I.L.M. at 1503.

195. 42 U.S.C. $§ 11603(\mathrm{~h})$.

196. 9 U.L.A. Part 1, at 123-331 (1988). For background on the UCCJA, see Anne Goldstein, The Tragedy of the Interstate Child: A Critical Examination of the Uniform Child Custody Jurisdiction Act and the Parental Kidnapping Prevention Act, 25 U.C. DAVIS L. REV. 845 (1992).

197. 9 U.L.A. Part 1, at 9-10 (Supp. 1991).

198. Missouri, New Mexico, Ohio, and South Dakota omit this section. Indiana has adopted a unique provision with respect to foreign decrees affecting children who are citizens of the United States: if a child is physically present in the United States and is likely to be moved outside the United States, the Indiana courts may modify the foreign decree if it is in the best interests of the child. Ind. Code $\$$ 31-1-11.6-25 (1987). One commentator has observed that as applied to abductions from contracting states under the Hague Convention, the Indiana statute is inconsistent with federal law and would run afoul of the Supremacy clause. See Levy, supra note 158.

199. The principles of the UCCJA may be used to locate the litigation in the child's home state or to recognize and/or enforce a foreign decree. See, e.g., Adkins v. Antapara, 850 S.W.2d 148 (Tenn. Ct. App. 1992), appeal denied, 1993 Tenn. Lexis 132 (Tenn. Mar. 22, 1993) (Panama was child's home state and Panama, not Tennessee, is appropriate forum for custody); Dixson v. Cantrell, 564 So.2d 1138 (Fla. Ct. App. 1990) (Netherlands decree entitled to recognition under UCCJA). But compare Schmidt v. Schmidt, 548 A.2d 195 (N.J. Ct. App. 1988) (UCCJA applicable to make valid foreign decrees enforceable, but its general jurisdictional principles do not apply to international cases). 
If a foreign custody decree has been entered and is consistent with the jurisdictional standards of the UCCJA, a state court in the United States enforces the decree by ordering custody to the party entitled to custody under the decree. The philosophy of the Act, similar to that of the Convention, allocates the responsibility of modifying the decree to the state that made the original custody award. Enforcement of a foreign decree under the UCCJA does not necessarily ensure return of the child to that country, however, although a judge might include as part of the order a direction that the abducting parent return the child to the custodial parent in the original state.

Procedures such as those provided for in Article 26 of the Convention, as implemented in 42 U.S.C. $\$ 11607$ (b)(3) (ICARA), authorizing an award of costs and expenses (including the costs for locating and returning the child) against the person who wrongfully removed or retained the child in a Convention case may also make the Hague remedy advantageous, although cost-shifting orders are also appropriate under the UCCJA. ${ }^{200}$ The Convention does not speak to the question of who takes physical custody when return is ordered. Rather, Article 12 of the Convention directs the relevant authorities to "order the return of the child forthwith."201 Section 11604(b) of ICARA provides that no court exercising jurisdiction over a Hague Convention proceeding may order a child removed from a person having physical control of the child unless state law is satisfied. $^{202}$ But section 11604(a) of ICARA also provides that a court exercising jurisdiction over a Convention action may take measures under federal

Professor Robert Levy has suggested that although the Hague Convention remedy cannot be used affirmatively when a child is wrongfully taken from a non-signatory state to the United States, the Hague Convention defenses should be available when return is sought under state law. Otherwise, he argues, a pursuing parent from a nonsignatory state has a better chance of achieving return than a parent from a state that is party to the Convention. See Levy, supra note 158.

200. Section 15 of the UCCJA authorizes an award of travel and other expenses, including attorneys' fees, when a custody decree is violated and must be enforced in another state. Section 11 of the UCCJA authorizes a court to require a party to pay travel and other necessary expenses of another party and the child if their appearance before the court is required.

201. The language of the Convention is "return of the child." It does not say to whom the child is to be returned and in context usually means return to the state of habitual residence, without specifying whether the abducting parent must give up physical custody. The Convention did not specify that the return should be to the state of habitual residence because of concern that in some situations the applicant may no longer be in the original state of habitual residence. See PEREZ-VERA REPORT, supra note 2, at 459; see also SECOND SPECIAL COMMISSION REPORT, supra note 7, at 22. Experience under the Convention indicates that in some cases the abducting party returns to the habitual residence with the child and in others there will be a turnover of the child to the party requesting return. Hague Convention, supra note 1 , art. 12, S. TREATY DOC. No. 11 at 9,19 I.L.M. at 1502 .

202. Some courts have been less than exact in this context. For example, in Tahan v. Duquette, 613 A.2d 486, 490 (N.J. Super. App. Div. 1992), a child who had been living with his father in New Jersey was ordered returned to Canada, the child's habitual residence. An existing custody order had granted custody to the mother and summer visitation to the father. The court ordered the child returned to Canada in accordance with the Canadian custody order. Without formally addressing the issue of enforcement of the Canadian decree under state law, the court ordered physical custody to be given to the mother in Canada, even though the father had physical custody for an extended period and indeed was entitled to custody via visitation rights under the existing Canadian order. 
or state law to protect the well-being of the child. ${ }^{203}$ Since the Convention does not expressly speak to the issue of who takes custody, it may be desirable to seek both enforcement of the foreign decree under the UCCJA and return of the child under the Convention. Indeed, in some situations, a parent whose child is taken to the United States from another country in violation of a decree may prefer to bring an action for enforcement under state law rather than a Hague petition for return of the child, particularly if the parent does not plan to return to the state of habitual residence. Or a party who thought that the state of habitual residence would be more likely to modify an existing decree could even prefer enforcement to return. But a party taking that route could risk a full plenary hearing in the refuge state by way of modification if rights under the Hague Convention are abandoned. ${ }^{204}$

In the absence of a decree, of course, an aggrieved party whose child has been wrongfully removed to, or retained in, the United States cannot bring an enforcement action. However, a proceeding for custody in the United States might still provide a viable alternative to a Convention proceeding. In the usual case, the aggrieved parent wants the child returned to the state of habitual residence for litigation of the custody issue there. But in some circumstances, the aggrieved parent might find it more convenient or desirable to litigate in the United States. If the child has been in the United States for a substantial time-even if it is not the child's habitual residence-there should be jurisdiction under the UCCJA. The question then arises whether a party may bring such an action for custody in an American court in lieu of an action for return of the child under the Convention and ICARA. Although the international treaty and federal statute would preempt state law if the retention of custody jurisdiction under state law were inconsistent with the treaty, the outlined scenario does not present any such inconsistency. The Convention (and statute) would seem only to provide a party whose child has been wrongfully removed in breach of custody rights with the option of having the child returned to the state of habitual residence, and not to preclude such party from submitting and consenting to the jurisdiction of a court in the United States. Specifically, Article 29 of the Convention provides that the Convention does not preclude a party who claims a breach of custody rights from applying directly to the judicial or administrative authorities of a contracting state, "whether or not under the [Convention provisions]."205 And, as noted earlier, ICARA expressly states that the

203. See, e.g., Klam v. Klam, 797 F. Supp 202 (E.D.N.Y. 1992) (ex parte warrant for delivery of child unnecessary where no extraordinary circumstances shown). For practical tips on using provisional remedies, see Robert D. Arenstein, The Hague Convention: Understanding and Litigating Under the Treaty, in NEW JERSEY INSTITUTE FOR CONTINUING LEGAL EDUCATION, INTERSTATE AND INTERNATIONAL CHILD CuSTODY 87, 93 (1992).

204. Article 16 of the Convention prevents a contracting state from deciding on the merits of a custody dispute once there is notice of a wrongful removal until there has been a determination that the child is not to be returned "unless an application under this Convention is not lodged within a reasonable time following receipt of the notice." Hague Convention, supra note 1, art. 16, S. TREATY DOC. NO. 11 at 10,19 I.L.M. at 1503 .

205. Id. art. 29, S. TREATY Doc. No. 11 at 12, 19 I.L.M. at 1504. 
remedies under the Convention are not exclusive. ${ }^{206}$ In Becker, ${ }^{207}$ where the husband came to the United States with the children and failed to return with them to Australia, the state of habitual residence, the mother brought both a custody action and a proceeding under the Convention in New Jersey. The court ordered return of the child and rejected the husband's argument that return of the child was improper because the wife had "waived" return by bringing a custody action in New Jersey. ${ }^{208}$

Nonetheless, it is incumbent upon counsel for an aggrieved party to refrain from participation in a full custody hearing in the state to which the child has been abducted, because once that step is taken, it may be too late to insist upon the Convention right of return. Article 16 of the Convention provides that the respective authorities of a contracting state to which the child has been taken shall not decide on the merits of rights of custody "until it has been determined that the child is not to be returned under this Convention or unless an application under this Convention is not lodged within a reasonable time following receipt of notice of the wrongful conduct." ${ }^{209}$ In several cases in the United States involving successive abductions, the parent who suffered the first abduction failed to request return and instead participated in a custody proceeding in the state where the child was taken. Then, after losing on the merits, the unsuccessful parent reabducted the child back to the original state, where the victorious parent requested and received return of the child under the Convention. The complicated facts of Sheikh $v$. Cahill, ${ }^{210}$ presented precisely this situation. In Sheikh, the child was born in the United States to a Pakistani father and Irish mother. First the father took the child from New York to Pakistan without the mother's consent, and the mother then reabducted the child to Ireland. Eventually, a New York custody order was entered as part of an uncontested divorce with custody of the child awarded to both parties. The child was to reside with the mother and the father's visitation was to be supervised. The mother subsequently took the child to England without the father's consent, and when the father finally located them, he brought a wardship proceeding in England. The English court made the child a ward of the English court, gave care and control to the mother, and extended the father's periods of visitation with the child in the United States. At the end of the first visitation in the United States, the father failed to return the child. The mother brought a proceeding under the Convention in the United States, and the father counterclaimed for custody. The father's position was that the mother herself had violated the initial New York decree, and therefore the English court's decision

206. 42 U.S.C. $\$ 11603(\mathrm{~h})$.

207. 15 Fam. L. Rep. (BNA) 1605 (N.J. Super. Ct., Morris Cty., Aug. 28, 1989), discussed supra at text accompanying note 64 .

208. Note, however, that a party who abandons a request for return and seeks only custody may waive rights under the Convention. See S. v. M., 50 R.F.L.(3d) 59 (Alberta C.A. 1993) (unwed father who did not pursue at trial a request for return of biological child waived any claim under Convention).

209. Hague Convention, supra note 1, art. 16, S. TREATY DoC. No. 11 at 10, 19 I.L.M. at 1503.

210. 546 N.Y.S.2d 517 (N.Y. Sup. Ct., Kings Cty., 1989). 
was a nullity. The New York court held, however, that the father had submitted himself to the jurisdiction of the English courts by requesting custody and participating in the English action. More importantly, he never attempted to use the New York decree as a basis for seeking a return to New York under the Convention in the English court. The New York court's position was that the father could have brought a Hague petition for return of the child in England, and having failed to do so, the arrangements established by the English court must be honored. More precisely, the decision regards the English court's custody order as determinative of the "custody rights" of the parties, with England in these circumstances as the habitual residence.

A similar situation occurred in the Tahan v. Duquette litigation, ${ }^{211}$ which involved a custody dispute between a Canadian mother and an American father living in New Jersey. An initial consent judgment was issued by the New Jersey court, granting joint custody and giving each parent physical custody on a fourteen-week alternating schedule. During her fourteen-week period, the mother had the child with her in Canada, but failed to return the child to the father in New Jersey pursuant to the New Jersey decree. The father first attempted to enforce the decree in Canada in June 1988 (note that the Hague Convention was not yet in force in the United States), but eventually converted the proceeding into a plenary custody action with both parents seeking custody. ${ }^{212}$ The Canadian court granted custody to the mother during the school year with visitation during the summer with the father. A subsequent appeal in Canada by the father was abandoned, but during the child's summer visitation in New Jersey, the father brought and succeeded in an application for permanent custody in New Jersey. When the mother later brought a proceeding in New Jersey under the Hague Convention, the lower court refused to return the child on the ground that the child had been in the United States for more than one year and need not be returned if settled in its new environment. The Superior Court reversed, however, holding that the mother had timely applied for return of the child under the Convention, that the child's habitual residence was Canada, and that the father wrongfully retained the child after his 1989 summer visitation. With respect to the one-year period, the court found that proceedings for return "had been commenced" within the one-year period since the time period ran from the time the child should have been returned and not from the date the visit began. ${ }^{213}$

Tahan, like Sheikh, may be a case where the father mistook his remedy in the foreign court. Unfortunately, in this case, the father could not have brought a Hague Convention proceeding because at the time he commenced proceedings

211. Tahan v. Duquette, 613 A.2d 486 (N.J. Super. Ct. App. Div. 1992); Duquette v. Tahan, 600 A.2d 472 (N.J. Super. Ct. App. Div. 1991).

212. By the time of these proceedings, the child was close to six years old and would be attending school, and the court indicated that it would be in the child's interest to alter the prior alternating threemonth arrangement.

213. Duquette v. Tahan, 600 A.2d at 475. 
in Canada the Convention was not yet in effect in the United States, and the limits on the retroactivity of the Convention probably precluded a Convention remedy from subsequently becoming available. ${ }^{214}$ But it is unclear why the father abandoned his attempt to enforce the New Jersey order in Canada or whether he pressed for a dismissal on the ground that New Jersey was the more appropriate forum to consider a modification of the prior New Jersey order. Clearly, after participating in the Canadian proceeding and subjecting himself to a Canadian decree, the father, by retaining the child in New Jersey, was "in breach of rights of custody attributed to ... the mother ... under the child's habitual residence."

One last variation with respect to the interrelationship of state custody law and the Convention deserves mention. A Convention proceeding should be brought in the state where the child is located. (If the child is no longer there, Article 9 of the Convention provides that the application be transmitted to the Central Authority of the appropriate contracting state.) Thus, if a child is wrongfully removed or retained outside of the United States, a Convention proceeding in that country is necessary to obtain return. ${ }^{215}$ In some situations, it may still be practical to bring a custody action in the United States, despite the absence of the child. Such a strategy may influence perceptions of whether "custody rights" have been breached or whether the parties and child are "habitually resident," even though such findings will not be binding on another contracting state hearing a petition for return of the child under the Convention. ${ }^{216}$ For example, in Aubry v. Aubry, ${ }^{217}$ the New York state court exercised jurisdiction under New York's custody jurisdiction statute (the UCCJA) and ordered the defendant to return the child to New York. Nonetheless, since the child was in Switzerland at the time, an action in Switzerland for return of the child, either under the Convention or otherwise, would be necessary if the

214. See supra text accompanying notes 112-15.

215. In one lower court New York case, Aubry v. Aubry, the court relied on the Convention to support its jurisdiction and granted temporary custody to a New York father, even though the child was in Switzerland. Swiss Citizen Living in U.S. Must Return Child to New York, 206 N.Y. L.J. 21 (1991) [hereinafter Swiss Citizen]. Although not expressly so stated in the Convention, an action for return is to be brought in the state where the child is located. Article 9 states that a Central Authority which believes a child is in another contracting state "shall directly . . . transmit the application to the Central Authority of that Contracting State." Hague Convention, supra note 1, art. 9, S. TREATY DOC. NO. 11 at 9, 19 I.L.M. at 1502. Within the United States, ICARA provides for a Convention proceeding to be brought in the state or federal court in the place "where the child is located at the time the petition is filed." 42 U.S.C. \$ 11603(b). Technically, neither the Convention or ICARA applied to the issue in Aubry, which involved an action by the father to obtain custody-a proceeding covered by the New York version of the UCCJA, not the Convention. The court did direct the mother to return the child to the father in the United States, but because the child was then in Switzerland, additional action in Switzerland might be necessary either for return of the child pursuant to the Hague Convention or for enforcement of the New York order under applicable Swiss law.

216. In Parsons v. Styger, 67 O.R.2d 1 (Ont. Sup. Ct. 1989), appeal dismissed, 67 O.R.2d 11 (Ont. C.A. 1989), a California judge had made findings of a wrongful removal as well as a habitual residence in California. The Ontario court, on a return petition, referred to those findings but emphasized that they were not binding. The Ontario court did, however, make the same findings and ordered return. 119.

217. See Swiss Citizen, supra note 215; see also discussion of case supra at text accompanying note 
defendant did not obey the New York court's order. Exercise of jurisdiction in the United States in these circumstances does not in any way affect the ability to bring an action for return of the child in the state to which the child has been removed or retained, and in most cases, such an action for return will be necessary. In Horlander v. Horlander ${ }^{218}$ the French mother took the children from the family home in Indiana and went to France. While there, she brought an action for divorce and custody; shortly thereafter the father filed his own marital action, including a petition for an emergency preliminary hearing on custody, in Indiana. The trial court had dismissed the father's action on the ground of the prior action in France, but the appellate court reversed. Under the UCCJA, the only reason for Indiana not to exercise its "home state" jurisdiction was if France was "exercising jurisdiction substantially in conformity with the Act." Because the children had been in France only for a short time, the Indiana appellate court held that France did not meet the alternative jurisdictional test of a "significant connection" as defined in the Act. ${ }^{219}$ In addition, it held that the Indiana trial court had abused its discretion in finding that France was a more convenient forum. Once the Indiana appellate court had spoken, the Indiana courts could exercise jurisdiction over the action and enter a decree, whether or not the defendant mother participated in the proceedings. But unless the mother complies with the decree, or France enforces it, the children will still be in France. The jurisdictional battling in Indiana will have accomplished little if the children are not returned to the United States, and it is the Convention remedy that can provide the return.

Subsequent events in the Horlander scenario illustrate the substantial advantages the Convention offers if correctly applied. In Horlander, the father did eventually commence a Convention proceeding in France for return of the children. In October 1990, the court of first instance in France ruled against Mr. Horlander, holding that he had "acquiesced" in their removal by offering in negotiations an overall custody property settlement, under which the children would have remained in Paris. ${ }^{20}$ The decision was affirmed by the Cour d'Appel de Paris in May $1991 .^{221}$ However, on further appeal, the Cour de Cassation, the highest civil court in France, held in July 1992 that Mr. Horlander had never manifested unequivocally and "de façon certaine" his intention to renounce his claim for return of the children. ${ }^{222}$ The decision is an important one in preventing the acquiescence defense from "driv[ing] a coach and four through the Convention. ${ }^{, 223}$

218. 579 N.E.2d 91 (Ind. App. 1991).

219. Id. at 96-97.

220. Judgment of Oct. 31, 1990 (Horlander v. Horlander), No. 90/37163, Trib. gr. inst. de Paris (Fr.) (on file with author).

221. Judgment of May 24, 1991 (Horlander v. Horlander), Cour d'Appel de Paris (Fr.) (on file with author).

222. Judgment of July 16, 1992 (Horlander v. Horlander), Cass. civ., 1992 Bull. Civ. L. No. 91-18177

(Fr.) (on file with author).

223. The language comes from C v. C, [1989] 2 All E.R. 465 (Eng. C.A. Dec. 14, 1988). 
There seems to have been little reason for Mr. Horlander to proceed in Indiana at all. It is true that the Indiana appellate court, though not citing to the Convention, rendered a decision consistent with it by ruling that Indiana as the habitual residence and not France was the proper forum for custody litigation. However, it is only with action by the French courts and/or authorities that return of the child is likely to be achieved. Of course, if the Indiana court eventually awards custody to the father, that order might be enforced by the French courts. But such a proceeding is not likely to be as effective or as expeditious as an action in France for return under the Convention. Unlike its treaty obligation to order return under the Convention, France is not required to enforce a U.S. custody judgment. In addition, Article 11 of the Convention requires that the authorities act "expeditiously in proceedings for the return of children," and if the relevant authority has not reached a decision within six weeks from the date of commencement of the proceedings, there is a right to request a statement of the reasons for the delay. Thus, in a case like Horlander, the French courts must proceed expeditiously. Nor should proceedings brought by the mother in France affect the outcome of the father's return petition ${ }^{224}$; even a decision by a French court giving the mother custody would not be a basis for refusing to return the children to the United States, although a court can take account of the reasons for such a decision in applying the Convention. ${ }^{225}$ Thus, when the Convention works properly and effectively, it offers substantial advantages for securing return of children wrongfully removed or retained. ${ }^{226}$

224. Abducting parties do often bring their own custody actions in the place where they have fled. In the United States, the standards of the UCCJA should cause a court to decline jurisdiction in situations where the habitual residence is in another contracting state. See, e.g., Pefaur v. Pefaur, No. 92-42571 FC(29) (Fla. Cir. Ct., Dade Cty., Apr. 15, 1992), aff'd, No. 92-1303, Fla. App., 3d Dist., Apr. 27, 1993 (available on Hilton BBS) (Florida has no jurisdiction over mother's action where children reside in Argentina). In addition, Article 16 of the Convention instructs the authorities of a contracting state to refrain from a decision on the merits of the custody dispute once it has received notice of a wrongful removal or retention.

225. Article 17 provides:

The sole fact that a decision relating to custody has been given in or is entitled to recognition in the requested State shall not be a ground for refusing to return a child under this Convention, but the judicial or administrative authorities of the requested State may take account of the reasons for that decision in applying this Convention.

Hague Convention, supra note 1 , art. 17, S. TREATY DOC. No. 11 at 10,19 I.L.M. at 1503 . Thus, I suppose that if a French court had previously determined that the father had been abusive to the children, it would be evidence of a possible Article $13 \mathrm{~b}$ defense. But even here, the correct result might well be to have the child return with the mother to Indiana and allow the Indiana court to decide custody.

226. Of course, we have seen situations where foreign courts have used one or another of the Convention defenses to avoid return of the child to the habitual residence. See, e.g, Judgment of Dec. 5, 1990 (Aubry v. Aubry), Trib. gr. inst. de Paris (Fr.), aff'd, Judgment of June 20, 1991, Cour d'Appel de Paris (Fr.) (on file with author), discussed supra at text accompanying notes 119-20. However, there is little reason to believe that Mr. Aubry would have had greater success if he pursued a custody action in New York instead of the Hague proceeding in France. The best he could have hoped for was to get a favorable custody order in New York, and if his wife would not voluntarily obey it, to try to enforce it in France. Given the outcome in the French courts in the Convention proceeding, it is unlikely that enforcement of a foreign custody order would have met with a better fate. 


\section{VII}

\section{SOME OBSERVATIONS ABOUT THE CONVENTION}

\section{A. Reasons for the Convention's Success: Treaty Structure and Hague Conference Oversight}

Both my study of this Convention and my observations at the Second Special Commission on the Operation of the Convention, which met on January 18-21, $1993,{ }^{227}$ indicate that the Convention on Child Abduction has been immensely successful. At a conference at the Duke Law School, where many of the articles appearing in this symposium were first presented, some of the difficulties impeding the smooth workings of other Hague conventions were discussed. The Abduction Convention appears to have avoided many of these problems. Given the immense differences in subject matter and approach of the various Hague conventions, it would be unwise to generalize too broadly about the attributes of the Abduction Convention or to assume that its features are necessarily transportable and transsubstantive. However, I do have some observations about the reasons for the success of the Abduction Convention, which may provide some useful insights concerning the convention process more generally.

First, The Hague Conference, under the guidance of First Secretary Adair Dyer on this project, was intimately involved in the planning, negotiation, drafting, and superintendence of the Abduction Convention. ${ }^{228}$ This stewardship was unique and is responsible in part for the Convention's success. The role of the Special Commissions-which have been convened twice since the adoption of the Convention-have also been invaluable in bringing together treaty and observer countries to discuss potential problems in the workings of the Convention and to share their collective experiences about how it functions. The result is an acute awareness and self-consciousness by treaty countries of the needs and perceptions of the treaty partners in carrying out the mandate of the Convention.

Second, the structure of the Convention with its focus on a limited number of issues for the judicial or administrative authorities has provided for ease of application in the various countries. Given the highly sensitive and volatile issues surrounding family law and custody in particular, the treaty's success can be attributed to its strategy of avoiding substantive "merits" and "best interest" evaluations and creating a "jurisdictional" set of rules. The Report accompanying the treaty outlined this jurisdictional objective:

227. The Second Special Commission was held at the Peace Palace in the Hague, January 18-21, 1993. SECOND SPECIAL COMMISSION REPORT, supra note 7, at 10. Forty-four countries were represented, 23 of which were parties to the Convention. Id. The First Special Commission met in October 1989 and was attended by representatives of 30 countries. Id.

228. The role of the Hague Conference in this Convention is set forth in more detail in Pfund, supra note 21 , at $36-37$. 
[I]t would be advisable to underline the fact that, as is shown particularly in the provisions of article 1, the Convention does not seek to regulate the problem of the award of custody rights. On this matter the Convention rests implicitly upon the principle that any debate on the merits of the question, i.e. of custody rights, should take place before the competent authorities in the State where the child had its habitual residence prior to its removal. . . .29

Implicit in this stated objective is a desire to avoid self-interested or advantageous resolutions by authorities in a country to which the parent took the child. While the primary rationale of the treaty is its two-pronged, interrelated goal of deterring abductions and directing adjudication of the merits of custody issues to the state of the child's habitual residence, the quest for standardized application on the return issues is a prerequisite to the fulfillment of these objectives. If Convention cases became subject to varying national approaches and perspectives, neither of the core objectives of the treaty would be attainable. Thus, only by ensuring that the child is returned and that the state of habitual residence is uniformly given the power to decide custody questions will abductions be deterred.

Toward this essential aim of standardized application, the drafters of the Convention attempted to provide uniform rules for the interpretation of the actual words and phrases of the text itself. Because many of the significant terms used by the Convention-for example, habitual residence, custody rights, grave risk of psychological harm-are inherently riddled with ambiguities and vulnerable to varying interpretations, the report accompanying the Convention attempted to create clear linguistic parameters for these words and phrases. In so doing, it expressed an intent to create a self-referential guide to applying the Convention in a standardized fashion:

This final Report must fulfil another purpose, viz. to supply those who have to apply the Convention with a detailed commentary on its provisions. Since the commentary is designed in principle to throw light upon the literal terms of these provisions, it will be concerned much less with tracing their origins than with stating their content accurately. ${ }^{230}$

Although it is an operational tradition of the Hague Conference not to define explicitly the terms of its treaties, ${ }^{231}$ the necessity of uniform interpretation led the drafters to make clear in certain articles and in the report the sense in which notions of custody and access rights are used. Recognizing that an "incorrect interpretation ... would risk compromising the Convention's objectives," both

229. PEREZ-VERA REPORT, supra note 2 , at 430.

230. Id. at 427.

231. Id. at 451 ("The Convention, following a long-established tradition of the Hague Conference, does not define the legal concepts used by it. However, in this article, it does make clear the sense in which the notions of custody and access rights are used, since an incorrect interpretation of their meaning would risk compromising the Convention's objects."). Although this caveat is ostensibly confined to these two terms, the Report-as discussed later-does frequently define other concepts and clarifies circumstances in which some of its particular terms are to apply. 
Article 5 and the report amplify these concepts. This relatively innovative exercise of definitional clarification attempts to eliminate the pitfalls of selfinterested translation and arbitrary interpretation into which other treaties have historically fallen. ${ }^{232}$

Specifically, the report goes to great lengths to outline the factual circumstances which comprise "custody rights," the term which triggers the applicability of the treaty itself. It explains that the term includes "rights relating to the care of the person of the child," while indicating that it is therefore a "more limited concept than 'protection of minors'...."233

Equally influential in the case law has been Article 5's contextual definition of the term "custody rights," which is determinative in many cases. Because varying domestic laws may construe "custody rights" in different ways, with certain parental powers included in the phrase in some countries but not in others, the treaty seeks to define as one constant component of the term the right to determine the child's residence. The inclusion of this power is intended to serve only as one example of the more general term "relating to the care of the person of the child," but it has been cited by courts in various countries as a guide to determining when such "custody rights" exist. The result has been that the treaty has created an autonomous treaty definition quite apart from domestic law interpretation of those circumstances which give rise to a breach of the Convention warranting return. ${ }^{234}$

Another linguistic feature of the Convention is the simultaneous drafting of the treaty in English and French and their use as equally authoritative languages for the text of the treaty. Until the United States became a member of the Hague Conference in 1964, French was the official language of all Hague Conventions. Since then, all treaties are written, adopted, and ratified in both English and French with the two being characterized as "equally authentic."235

One advantage of the dual use of English and French is that any ambiguity in the wording in one language may be clarified by reference to the wording in the other language, where the alternative may contain more precision. The report accompanying the treaty emphasizes the value of consulting the second language where doubt about meaning may exist in the first. One example comes from Article 1. The report explains that Article 1 is in no way intended to

232. See, e.g., Christopher B. Kuner, The Interpretation of Multilingual Treaties: Comparison of Texts Versus the Presumption of Similar Meaning, 40 INT'L \& COMPARATIVE L.Q. 953, 953 (1991) ("[A] number of diplomatic incidents and even wars have been triggered by differences between language versions of multilingual treaties.").

233. PEREZ-VERA REPORT, supra note 2, at 451-52.

234. See, e.g., C v. C, [1989] 2 All E.R. 465 (Eng. C.A. Dec. 14, 1988) (holding that a father who had only "guardianship" under an Australian custody decree should be understood to possess "custody rights" within the contextual meaning of the Convention); see also Lindsay Curtis, The Hague Convention on the Civil Aspects of International Child Abduction: The Australian Experience, 15 COMMONWEALTH LAwS BULL. 627, 629 (April 1989) (exploring substantive differences between Australian domestic laws and Hague Convention for purposes of defining "wrongful removal").

235. See Kurt H. Nadelmann \& Arthur T. von Mehren, Equivalencies in Treaties in the Conflicts Field, 15 AM. J. COMP. LAW 195 (1967). 
mandate that signatories alter their internal law in order to comport with the provisions of the Convention, but that it is intended only to encourage signatories to abide by the spirit of the Convention when interpreting their own domestic laws. ${ }^{236}$

Also, the report occasionally will indicate which of the two languages more accurately reflects the intent of the Convention where clarification is not possible through a comparative assessment of the two terms alone. ${ }^{237}$ One example can be found with respect to the French and English phrases in Article 8 delineating the type of information required to be provided to the Central Authority when reporting an abduction or retention of a child. The French phrase is more general and does not appear to require the nationality of the abductor, whereas the English version indicates that this information is necessary. The report expresses its preference for the English version:

[T]here is an inconsistency between the French and English texts regarding the "information concerning the person alleged to have removed or retained the child." It would be advisable to follow the English text here, since it is more comprehensive, especially as regards its reference to the nationality of the alleged abductor, a fact which will sometimes prove decisive in efforts to locate the child. ${ }^{238}$

Though the process of having two "equally authentic" texts can engender difficulties, ${ }^{239}$ the Child Abduction Convention has not produced instances where the lack of equivalency between particular terms has rendered inconsistent decisions. Perhaps as more countries join and have the treaty translated into their own languages, questions about linguistic equivalencies will surface more prominently. ${ }^{240}$ But the Convention's self-referential use of "autonomous" terms, such as "habitual residence" and "custody rights," may limit the problem

236. PÉREZ-VERA REPORT, supra note 2, at 444.

237. Compare, e.g., Article 33, section 3 of the Vienna Convention on the Law of Treaties ("The terms of the treaty are presumed to have the same meaning in each authentic text.") and Article 4 ("W]hen a comparison of the authentic texts discloses a difference of meaning which the application of Articles 31 and 32 does not remove, the meaning which best reconciles the texts, having regard to the object and purpose of the treaty, shall be adopted."). Vienna Convention on the Law of Treaties, May 23, 1969, S. TREATY DoC. No. 1, 92d Cong., 1st Sess., 8 I.L.M. 679, 682, 693.

238. PÉrez-VERA RePort, supra note 2, at 440 . Specifically, Article 8 delineates the type of information which an application to a nation's Central Authority should contain. Section 8a's English terms connote a broad descriptive narrative, including all relevant information to describe a person. In contrast, the French phrase often has a more limited meaning, often used exclusively to refer to a person's name. Id.

239. See Nadelmann \& von Mehren, supra note 235, at 195.

240. See generally Kuner, supra note 232, at 954, 958:

Given the inevitability of differences between language versions, an obvious defect of the presumption [of equivalence] is that it works as a rule of enforced ignorance which allows such differences to go undetected. ... The result of this state of affairs can be exemplified by the U.S. Supreme Court case Foster v. Neilson in which the Court consulted only the English version of a treaty with Spain and held that it was not self-executing. Four years later the Court was forced to reverse itself when a discrepancy in the two language versions was brought to its attention. 
to a certain degree. ${ }^{241}$ In addition, both the report and the text of the treaty express general guidelines for interpretation by emphasizing the Convention's objectives and the need to render decisions compatible with those objectives. ${ }^{242}$

Such guidance has helped avoid technical or parochial interpretations of the Convention. One example is illustrated by the English case $C v . C,{ }^{243}$ where an Australian mother took the child to England without the consent of the father. Both parents had consented to a custody decree in Australia, where the wife was granted "custody" and both parents were given "joint guardianship." The English court dismissed a Convention petition brought by the father to secure return of the child to Australia, holding that the father merely had "guardianship" over the child, not "custody," and that he thus had no rights under the Convention. The Court of Appeal reversed, holding that the father did have "custody rights" within the meaning of Article 5 since the Australian guardianship order gave him the right to determine the child's place of residence. The Court repeatedly referred to the general language of the treaty text and the report, and concluded that the decision to return would best promote the objectives of the Convention. Acknowledging that the father lacked "rights of custody" under Australian law, ${ }^{244}$ the Court concluded that the decisions rendered in Convention cases should be construed to promote the underlying intent of the Convention as expressed in both its text and report.

To a large extent, the interpretation in $C v . C$ was uncharacteristic of a British court. England has traditionally favored a literal interpretation of all legal documents-whether domestic or international in origin. ${ }^{245}$ Unlike U.S. courts, which are receptive to a broader context for interpretation, the English courts have tended to analyze language as self-contained and adopted a form of textual objectivity. Rather than attempting to discern the meaning most plausible in a particular context, the British often assume that words have universal meaning. ${ }^{246}$ In $C v$. $C$, the usual British practice of interpretation would have led to the conclusion that the Convention was inapplicable, since the Convention applies only to cases of "rights of custody" and the Australian custody decree by its terms excluded the father from custody and restricted him to "guardianship." The lower court judge reasoned quite simply and "objective-

241. The habitual residence concept had been adopted by other Hague Treaties precisely to avoid the interpretative difficulties created by use of the term "domicile." See Nadelman \& von Mehren, supra note 235 .

242. PEREZ-VERA REPORT, supra note 2, at 430.

243. [1989] 2 All E.R. 465 (Eng. C.A. Dec. 14, 1988).

244. See Anthony Dickey, Rights of Custody Under the Child Abduction Convention, FAM. LAW, Jan.-Feb. 1990, at 85 .

245. Paul Gormley, Treaty Interpretation: Theory and Reality, 13 DALHOUSIE L.J. 874, 878 (1990) (book review).

246. Id. at 879 ("Of course, the differences between the U.S. and U.K. practices are also enunciated in the analysis, since the British rely on the textual approach-or textual objectivity-whereas greater deference is placed on the travaux préparatoires of the treaty by a majority of American jurists. Significantly, the author shows that American courts have rejected the notion of rules of interpretation as obligatory legal norms. . . . Rather, the various canons of interpretation are used as guides."). 
ly" that custody was not the equivalence of guardianship. However, the Court of Appeal relied upon the intent of the Convention to conclude that a contextual and not an objective standard was demanded. The clear guidance given by the treaty and its accompanying Report have been significant in interpretation of the treaty.

A third structural aspect of the Convention contributing to the Convention's success is the two-way role of the Central Authorities and their activities respecting both "incoming" and "outgoing" cases. The Central Authority concept was designed not merely as a passive depository for papers and documents but as an active and dynamic institution to facilitate communication between the respective contracting states. Information exchanges and status reports are contemplated as part of the continuing dialogue between Central Authorities. Countries have stressed the importance of improved communications between Central Authorities, including prompt acknowledgements of the receipt of applications and expeditious channeling of all follow-up information. Continuing updates regarding attempts made to locate children, the provision of counsel, the status of proceedings, and enforcement steps are essential aspects of this process.

The enactment of implementing legislation in various contracting states has also been quite useful in assuring that the Convention functions smoothly within the context of particular legal institutions. For example, England, in its implementing legislation, eliminated Article 20 so as not to introduce a "human rights" or "constitutional norm" into its law. ${ }^{247}$ In other states, expedited rules of procedure have been enacted to meet the time limits contemplated by the Convention. Some countries have included provisions in their legislation to permit decisions to be enforceable immediately, whether or not an appeal is taken. $^{248}$ In the United States, a State Department Advisory Study Group, ${ }^{249}$ under the guidance of Mr. Peter Pfund, Assistant Legal Adviser for Private International Law at the State Department, participated in efforts to draft the American implementing legislation. ${ }^{250}$ Among the issues it addressed was the appropriate allocation of judicial responsibility between the state and federal courts. ${ }^{251}$ Shortly after signing the treaty, the Supreme Court had held in Thompson v. Thompson ${ }^{252}$ that the Federal Parental Kidnapping Prevention Act ("PKPA") ${ }^{253}$ - the federal statute providing for enforcement and recognition of sister-state custody decrees when certain jurisdictional standards have

247. Child Abduction and Custody Act C.60, sch. I, ch. 3 (1985).

248. SECOND SPECIAL COMMISSION REPORT, supra note 7, at 232-33.

249. The author served as a member of that advisory group.

250. For a general discussion of the activities of the study group, see Lawrence Stotter, The Light at the End of the Tunnel: The Hague Convention on International Child Abduction Has Reached Capitol Hill, 9 HASTINGS INT'L \& COMP. L. REV. 285, 298-99 (1986).

251. Although the Hague Convention was probably self-executing, implementing legislation was thought desirable to clarify the state-federal relationship under the Convention, both with respect to interstate cooperation as well as adjudication. See Frank, supra note 6, at 415, 465-74.

252. 484 U.S. 174 (1988).

253. 28 U.S.C. $\$ 1738$ A. 
been met-did not provide for federal jurisdiction in the first instance to determine the validity of conflicting custody decrees. Thus, there was some sentiment that providing federal jurisdiction over Convention "return" cases would be inconsistent with that decision and a concern that a grant of federal jurisdiction for Convention cases would be perceived as giving international custody cases a higher priority. But Congress, with the advice of the Advisory Group and the State Department, authorized concurrent jurisdiction in both state and federal courts as part of the implementing legislation. That compromise seems appropriate since the Convention does not entrust to judicial authorities general decisions about custody as do ordinary domestic custody disputes, but rather poses the more limited inquiry of whether certain custody rights have been breached as a prerequisite to an order to return. Thus, traditional custody inquiries are generally not in order, and unlike domestic jurisdictional fights, ${ }^{254}$ there are no prior jurisdictional bases to evaluate. At the same time, some of the Convention defenses, such as the 13b "grave risk" or "intolerable situation" defense, can involve courts in mini-hearings about the welfare of a child, much like traditional state court custody cases. Additionally, where interim or provisional measures need to be taken, it is the state courts that probably have the more extensive expertise. In the short run, it appears that this perception may dominate, since most of the return applications have been filed in state courts.

Within the United States, the State Department's continuing role and operation as the Central Authority has been extremely important in ensuring a cooperative relationship with other countries. The United States's failure to bear the costs and expenses of foreign applicants' petitions under the Convention has been the subject of serious criticisms by other treaty countries. ${ }^{255}$ As the U.S. Central Authority, the State Department has engaged in a continuing effort to enlist the assistance of the private bar in obtaining the services of attorneys on a pro bono or reduced fee basis. By both helping to identify private counsel and providing information to such counsel, as well as keeping our requesting treaty partners abreast of proceedings here, the State Department has played a vital role. ${ }^{256}$ More needs to be done. Establishing a more extensive network of

254. Under the UCCJA and the PKPA, custody decrees of a sister state are enforceable only if the forum rendering the decree met jurisdictional standards identified by the respective statutes.

255. See SECOND SPECIAL COMmission REPORT, supra note 7, at 245: "The absence of a comprehensive legal aid system ... in the United States accentuated the effect of the reservation, since the Central Authority had to expend much time and effort in trying to obtain pro bono counsel for applicants who could not afford to retain a private attorney."

256. See Pfund, supra note 21, at 48-51. 
private lawyers and identifying public resources ${ }^{257}$ to aid in the effectuation of the responsibilities and obligations under the treaty remain critical goals.

\section{B. Some Remaining Problems}

1. Broader Adoption of the Treaty: Cultural Issues. Both the statistics and the cases, foreign and U.S., indicate that the treaty has been quite effective in deterring wrongful international abductions and retentions in treaty countries. Of course, a substantial number of countries have not yet acceded to or ratified the Convention, and obviously those countries may continue to be attractive havens for abductors. ${ }^{258}$ However, an abducting parent does not usually just seek a safe haven, but often returns to his or her "home country" where there is family or other support systems. Thus, the fact that a large number of countries have adopted the Convention has contributed to its success. Still, the number of abductions to non-signatory countries warrants concern and indicates the need for more nations to become parties to the Convention. ${ }^{259}$ It will be

257. For example, CAL. FAM. CODE $\S \S 3130-3131$ (West 1994) authorizes state authorities to take action to locate or return a child, or both. Under this provision (formerly CAL. CIV. CODE $§ 4604$ ), district attorneys in California have brought Hague petitions for return of children in California and assisted left-behind parents in pursuing a Hague remedy abroad. The California system and the role of its district attorneys is described in Gloria DeHart \& Raquel M. Gonzalez, The Role of Central Authorities: The California Model, in ABA SYMPOSIUM, supra note 9. The Final Report of the Obstacles to the Recovery and Return of Parentally Abducted Children Project recommends enactment by all states of a custody enforcement statute modeled upon the California statutory scheme. See DEPARTMENT OF JUSTICE OBSTACLES TO THE RECOVERY AND RETURN OF PARENTALL Y ABDUCTED ChILDREN (Linda K. Girdner \& Patricia M. Hoff eds. 1993).

258. See, e.g., Mezo v. Elmergawi, 855 F. Supp. 59 (E.D.N.Y. 1994) (Neither Hague Convention nor ICARA are applicable where children were taken from the U.S. and brought to Egypt and then to Libya). Nor can applicants seeking return of a child habitually resident in non-signatory countries use the Treaty or ICARA to obtain return of a child brought to the United States from such countries. Consider the situation in Mohsen v. Mohsen, 715 F. Supp. 1063 (D. Wyo. 1989), where the father, a citizen of Bahrain, and the mother, a citizen of the United States, lived with their daughter in Bahrain for several years. While on a visit to the United States, the mother sought a divorce and refused to allow the father access to his daughter. Conceding that Bahrain was not a signatory to the Convention, the father sought return of the child under ICARA, contending that the Act "stands alone from the Convention." Id. at 1065 . In rejecting the father's application, the court first observed that the Convention applied only to a child who was habitually resident in a contracting state immediately before any breach of custody rights, thereby creating an incentive for all nations to become signatories. In addition, it held that the Act did not create additional rights but empowered courts in the United States to determine "only rights under the Convention." Id. (citing 42 U.S.C. $\$ 11601$ (b)(4)). Of course, other remedies under state law, including Article 23 of the UCCJA, might have been available to the petitioner. See, e.g., Adkins v. Antapara, 850 S.W.2d 148 (Tenn. Ct. App. 1992) (applying UCCJA to dismiss mother's custody action in Tennessee where mother had taken children from their habitual residence in Panama). Courts in other countries have applied the philosophy of the Hague Convention in non-Convention cases and ordered return. See, e.g., Re S, [1994] 1 Fam. L. Rep. 297 (Eng. C.A. Dec. $17,1992)$ (ordering return of child to Pakistan, despite fact that Pakistan is not a signatory to the Convention).

259. In 1986, reported cases of child abduction from the United States totaled 256, with 18 taken to Africa, 62 to Central and South America and the Caribbean, 36 to East Asia and the Pacific, and 70 to the Near East and South Asia, including the Middle East. See Cathy S. Helzick, Note, Returning United States Children Abducted to Foreign Countries: The Need to Implement the Hague Convention on the Civil Aspects of International Child Abduction, 5 B.U. INT'L L.J. 119, 120 (1987). Only 92 of the 276 abductions ended up in Europe and Canada, where the overwhelming number of treaty signatories are. 
important to induce non-Western countries to join the Convention, but ironically, the addition of non-Western nations may simultaneously affect interpretations of it.

Reasons for wide acceptance of the treaty are several: its "jurisdictional" structure, its goal of transcultural objectivity, and its sensitivity to national and judicial sovereignty. With the exception of the Article 13b exceptions, the Convention is clear that the state to which the child is abducted shall order return of the child and shall not render social, moral, or judicial assessments regarding the appropriate outcome of the custody case itself. Underlying the treaty is the notion that the state of habitual residence is the appropriate forum to render any substantive custody judgment, thereby respecting the sovereignty and cultural values of the signatory states. Article $1 \mathrm{~b}$ of the Convention explicitly mandates that the "rights of custody and of access under the law of one Contracting State are effectively respected by other Contracting States."260 Philosophically, the Convention implicitly advocates that contracting states not impose their own respective standards of family morality or sociology onto cases properly decided in another state, but instead must defer in the name of judicial and cultural objectivity.

So far, judicial authorities construing the Convention have heeded those admonitions. The Article $13 \mathrm{~b}$ exceptions, although a potential vehicle for imposing nationalistic and subjective notions of family structures on the particular circumstances of the child and parents involved in the Convention proceeding, have not been so used by any of the contracting states. However, as more culturally diverse countries ratify the treaty, notions of "family," "parenting," "custody," and "best interests" may become more complicated and precipitate exceptions to the return remedy. Step-parents often become legal guardians or even adopted parents of their spouse's children; surrogate parents via artificial insemination are becoming more common; and homosexual couples are legally able to create family relationships in many states. Of course, Article $1 \mathrm{~b}$ of the Convention mandates that contracting states defer to the custody laws of the state of habitual residence to determine whether a "custody right" has been infringed. Thus, varying conceptions of "family" and "parents" should be irrelevant in the treaty's application, since states technically are required to return the child when such rights of custody are interfered with. However, one can easily imagine a contracting state invoking an Article 13b exception to avoid

\footnotetext{
These statistics underscore the importance of inducing many more countries, including non-Western ones, to join the treaty. See also Rebecca L. Hegar \& Geoffrey L. Grief, Parental Kidnapping Across International Borders, 34 INT'L SOC. WORK 353 (1991) (profiling a sample of families where children were abducted across international borders). For a general discussion of the problem of "haven states," see Monica M. Copertino, Comment, Hague Convention on the Civil Aspects of International Child Abduction: An Analysis of its Efficacy, 6 ConN. J. INT'L L. 715 (1991). The enactment of the International Parental Kidnapping Crime Act of 1993, 18 U.S.C. \& 1204, discussed supra note 7, may have increased the ability of the United States to effectuate the return of children who have been taken to non-Hague countries.
}

260. Hague Convention, supra note 1, art. 1b, S. TREATY DOC. No. 11 at 9, 19 I.L.M. at 1501. 
ordering a child to return to a homosexual home, despite its legality and acceptance in the state of habitual residency.

In addition, some premises of the Convention may not be universally accepted. The Convention presumptively declares that the "best interests" of the child are served by preventing abductions and ordering the return of the child: "Now, the right not to be removed or retained in the name of more or less arguable rights concerning its person is one of the most objective examples of what constitutes the interest of the child."261 Some nations, particularly those of Islamic influence, do not conceive of the family as constituted by two equal parents with equal rights of access to, or influence over, their children. ${ }^{262}$ These countries accept a theological absolute of the male as unchallenged monarch over the family. Consequently, the "best interests of the child" are defined synonymously with the decisions of the father, and it is difficult to conceive of an Islamic court ordering a father to return a child when a mother objects, for example, to a move to an Islamic country. Of course, the accession provisions offer some protection, and a country can withhold its accession to the Convention with a particular country. As part of the accession process, acceding countries furnish their family law legislation.

From the perspective of the existing treaty countries, a more politically and culturally diverse convention may mean that administrative and judicial authorities will engage in a more nationalistic approach. Quite apart from subjective notions of morality and sociology relating to the particular circumstances of the child and its parents, the defense of whether returning the child will result in "grave psychological harm" or creation of an "intolerable situation" is likely to lead a court to inquire into conditions in the other country or possible judicial outcomes there. For example, in Renovales $v$. Roosa, ${ }^{263}$ involving the abduction from Spain, the U.S. court ordered return of the child, despite the Article $13 \mathrm{~b}$ defense by the mother that the father had been abusive and psychologically harmful to the children. Although the court dismissed the defense, the court reasoned that there would be no grave psychological risk to ordering the return because Spain had a judicial system which afforded due process and because the Spanish judicial system was equipped with adequate mechanisms to evaluate the best interests of the children. Although the court respected the judicial competence and national sovereignty of Spain sufficiently to feel comfortable rejecting the Article $13 \mathrm{~b}$ defense, its willingness to assess the nature of Spanish societal norms and its judiciary may indicate an inclination and temptation to test the state of habitual residence for the existence of minimal cultural and judicial standards compatible with its own. Spain, as a Western

261. PÉREZ-VERA REPORT, supra note 2, at 431.

262. Note, of course, that the U.N. Convention on the Rights of the Child states a principle of the child's access to both parents (Article 9), and that several Middle Eastern and African countries are signatories to that Convention. Convention on the Rights of the Child, Nov. 20, 1989, 28 I.L.M. 1448 (1989).

263. No. A 91-0392232-S, 1991 Conn. Super. LeXIS 2215 (Conn. Super. Ct. Sept. 27, 1991). 
nation which shares fundamental notions of social norms and family with the United States, was viewed as an acceptable forum to adjudicate custody. Perhaps Iraq, or less extremely, Ethiopia or Indonesia, would not have been.

These cultural issues are not unique to the Child Abduction Convention, but are only a piece of the reality facing the continuing effort to forge consensus among nations about international legal standards generally. ${ }^{264}$ Indeed, the Convention, with its clear objective of return and limited issues for judicial interpretation, has adopted a useful strategy for achieving those ends. But it remains to be seen whether non-Western nations perceive the treaty to be "culturally neutral" in form only and therefore will refuse to join the treaty. Alternatively, if the treaty does gain broader adoptions, the broader cultural and political diversity could be a catalyst for more subjective judgments by contracting states and could ultimately undermine the formal and structural cultural neutrality for which it strives.

2. Beware the Child Savers. Efforts by well-intentioned child savers could also serve to frustrate the objectives of the Convention. Certainly, it is hard to quarrel with rhetoric about the child's "best interests," and the more convincing any particular individual claim, the weaker is the case for ordering return. However, Article 13b defenses are proliferating as abducting parents attempt to stave off return orders in the name of the child's welfare. ${ }^{265}$ Attempts to frustrate return under the guise of best interests, if allowed to succeed, could undermine the Convention and transform its procedural framework into one of substance. Indeed, the Convention presumptively declares that the best interests of the child are in fact served by preventing abductions and ordering the return of the child:

the struggle against the great increase in international child abductions must always be inspired by the desire to protect children and should be based upon an interpretation of their true interests. Now, the right not to be removed or retained in the name of more or less arguable rights concerning its person is one of the most objective examples of what constitutes the interests of the child. ${ }^{266}$

A number of courts have expressly commented upon that connection. In Murray v. Director, Family Services, ${ }^{267}$ the Full Family Court of Sydney Australia rejected any inconsistency between the Hague Convention and the U.N. Convention on the Rights of the Child:

... the Hague Convention is predicated upon the paramountcy of the rights of the child.

It proceeds upon the basis that those rights are best protected by having issues as to

264. See generally Gormley, supra note 245, at 874. Cf. Martin A. Rogoff, International Politics and the Rule of Law: The United States and the International Court of Justice, 7 B.U. INT'L L.J. 267 (1989).

265. See, e.g., the comments of Judge Ferrante in Lauder-Frost v. Lauder-Frost, FD-16-3525-91 (N.J. Super. Ct., Passaic Cty., Feb. 11, 1991) (on file with author), where the mother alleged she took the child because she was in fear of the father, and the judge observed that allegations of this type are becoming quite commonplace in custody cases. See also cases discussed, supra, at text accompanying notes 133-62.

266. PEREZ-VERA REPORT, supra note 2, at 431.

267. Appeal No. EA51, File No. CA 1162 (Austl. Full Fam. Ct., Sydney, Oct. 6, 1993) (on file with author). 
custody and access determined by the Courts of the country of the child's habitual residence, subject to the exceptions contained in Article 13.

The fact that issues relating to the welfare of the child are not relevant to a Hague Convention application is because such an application is concerned with where and in what court issues in relation to the welfare of the child are to be determined. ${ }^{268}$

Even though most courts have rejected defenses asserted under Article 13b, extensive hearings on "grave risk of psychological harm" or "intolerable situations" lengthen the proceedings and undercut the expeditious procedure envisioned by the Convention. ${ }^{269}$ For example, the Connecticut court in the Renovales case ${ }^{270}$ rejected the Article $13 \mathrm{~b}$ defense but conducted an extensive hearing to ascertain whether return might cause psychological harm to the child. Recognizing the need to avoid such lengthy proceedings, the New Jersey appellate court in Tahan $v$. Duquette ${ }^{271}$ limited the scope of hearings on such defenses by excluding evidence related to evaluations of comparative parental fitness and lifestyles. The court observed that the proffered evidence was more appropriate to "merits" issues, properly considered in a plenary custody proceeding in the place of habitual residence. To the extent that de facto custodial relationships should not be interfered with in order to protect the child, it is possible to have the parent return with the child and await custody proceedings in the state of habitual residence. ${ }^{272}$ In other situations, children are returned to authorities in the state of habitual residence and not to the other parent. ${ }^{273}$ Thus, when allegations of serious harm are made, a court ordering return can fashion interim arrangements, whether with the custodial parent or with a third party, to ensure the safety of the child. ${ }^{274}$ Alternatively, if the problem in ordering return of the child with the custodial parent is one of financial hardship, a court might require payments for housing and support during that period. When these types of options are available, it is likely that extensive hearings on the risk of harm to the child can be avoided altogether.

268. Id

269. The length of proceedings as well as the appeals process has resulted in excessive delays in getting children returned both in the United States and abroad. See Cornec, supra note 120, at 148-51. Courts in some countries have stressed the summary nature of return proceedings and proceed only on affidavit evidence, without direct testimony or an opportunity for cross-examination. See Gazi v. Gazi, Appeal No. EA85, File No. SY9127 (Austl. Full Fam. Ct., Sydney, Dec. 18, 1992) (available on Hilton BBS).

270. Renovales v. Roosa, No. 91-0392232-S, 1991 Conn. Super. LEXIS 2215 (Conn. Super. Ct. Sept. $27,1991)$, discussed supra text accompanying notes 128-30.

271. 613 A.2d 486, 488 (N.J. Super. Ct. App. Div. 1992), discussed supra text accompanying notes 133-38.

272. See supra text accompanying notes 146-53.

273. See, e.g., Murray v. Director, Family Services, Appeal No. EA51, File No. CA 1162 (Austl. Full Fam. Ct., Sydney, Oct. 6, 1993) (on file with author) (noting that under Australia's regulations, return is to New Zealand Department of Justice and not to the husband, and that New Zealand courts can determine veracity of wife's allegations of husband's violence).

274. See, e.g., Parsons v. Styger, 67 O.R.2d 1 (Ont. Sup. Ct. 1989) (supervision and assistance of Canadian Central Authority for return of children to California eliminates risk of harm), appeal dismissed, 67 O.R.2d 11 (Ont. C.A. 1989); Zimmermann v. Zimmermann, No. 91-14556-S (Tex. Dist. Ct., Dallas Cty., Oct. 14, 1991) (available on Hilton BBS) (no grave risk if children ordered returned in company of their mother). 
When allegations of serious harm are made, a hearing should first focus on whether interim arrangements made as part of the return process can eliminate the threat. Only if the answer to that question is in the negative should the court in the requested state proceed to a full-scale hearing to determine whether the defense can be substantively established.

3. Unanswered Questions. My final set of concerns about the treaty relate to the lack of relevant empirical data as to the eventual merits outcomes of the return cases. There has been little follow-up to the Convention cases I have surveyed. The limited anecdotal evidence we have suggests that return has been effected once it has been ordered, although there have been enforcement problems in certain countries. But we know very little about the decisionmaking that ultimately occurs in the return state. Is there eventually a fair and impartial custody hearing in the state to which the child is returned? Or is it ultimately hometown justice with a nationalistic flavor that is dispensed? Technically, the final outcome may not be relevant to whether the treaty itself is effective, since its object is return of the child. But if the broader hope and objective is to deter abductions, the return of the child must be coupled with fair minded decisionmaking by the requesting state if we are to expect nation-states to continue to effectuate the treaty and parties to refrain from self-help. Thus, additional research and further study of this type will be important for any final evaluation about the success of the Child Abduction Treaty. 
